The Impact of Interest Rate Risk on Bank Lending Toni Beutler, Robert Bichsel, Adrian Bruhin and Jayson Danton

SNB Working Papers

4/2017 


\section{DISCLAIMER}

The views expressed in this paper are those of the author(s) and do not necessarily represent those of the Swiss National Bank. Working Papers describe research in progress. Their aim is to elicit comments and to further debate.

\section{COPYRIGHT $\odot$}

The Swiss National Bank (SNB) respects all third-party rights, in particular rights relating to works protected by copyright (information or data, wordings and depictions, to the extent that these are of an individual character).

SNB publications containing a reference to a copyright (C) Swiss National Bank/SNB, Zurich/year, or similar) may, under copyright law, only be used (reproduced, used via the internet, etc.) for non-commercial purposes and provided that the source is mentioned. Their use for commercial purposes is only permitted with the prior express consent of the SNB.

General information and data published without reference to a copyright may be used without mentioning the source. To the extent that the information and data clearly derive from outside sources, the users of such information and data are obliged to respect any existing copyrights and to obtain the right of use from the relevant outside source themselves.

\section{LIMITATION OF LIABILITY}

The SNB accepts no responsibility for any information it provides. Under no circumstances will it accept any liability for losses or damage which may result from the use of such information. This limitation of liability applies, in particular, to the topicality, accuracy, validity and availability of the information.

ISSN 1660-7716 (printed version)

ISSN 1660-7724 (online version)

C 2017 by Swiss National Bank, Börsenstrasse 15,

P.O. Box, CH-8022 Zurich 


\title{
The Impact of Interest Rate Risk on Bank Lending
}

\author{
Toni Beutler, ${ }^{\ddagger}$ Robert Bichsel, ${ }^{\ddagger}$ Adrian Bruhin ${ }^{\S}$ and Jayson Danton ${ }^{\S}$
}

January 16, 2017

\section{Working Paper}

\begin{abstract}
In this paper, we empirically analyze the transmission of realized interest rate risk - the gain or loss in a bank's economic capital caused by movements in interest rates - to bank lending. We exploit a unique panel data set that contains supervisory information on the repricing maturity profiles of Swiss banks and provides us with an individual measure of interest rate risk exposure net of hedging. Our analysis yields two main results. First, the impact of an interest rate shock on bank lending significantly depends on the individual exposure to interest rate risk. The higher a bank's exposure to interest rate risk, the higher the impact of an interest rate shock on its lending. Our estimates indicate that a year after a permanent 1 percentage point upward shock in nominal interest rates, the average bank in 2013Q3 would, ceteris paribus, reduce its cumulative loan growth by approximately 300 basis points. An estimated $12.5 \%$ of the impact would result from realized interest rate risk weakening the bank's economic capital. Second, bank lending appears to be mainly driven by capital rather than liquidity, suggesting that a higher capitalized banking system can better shield its creditors from shocks in interest rates.
\end{abstract}

Disclaimer: The views, opinions, findings, and conclusions or recommendations expressed in this paper are strictly those of the author(s). They do not necessarily reflect the views of the Swiss National Bank. The SNB takes no responsibility for any errors or omissions in, or for the correctness of, the information contained in this paper.

JEL classification: E44, E51, E52, G21

Keywords: Interest Rate Risk; Bank Lending; Monetary Policy Transmission

Corresponding Author: Adrian Bruhin, University of Lausanne, Faculty of Business and Economics (HEC Lausanne), 1015 Lausanne, Switzerland; email: adrian.bruhin@unil.ch; phone: +41 (0)21 6923486

\footnotetext{
${ }^{\ddagger}$ Swiss National Bank, Financial Stability, 3001 Bern, Switzerland

${ }^{\S}$ University of Lausanne, Faculty of Business and Economics (HEC Lausanne), 1015 Lausanne, Switzerland
} 


\section{Acknowledgements}

We are grateful for the insightful comments from an anonymous referee, Stefanie Behncke, Frederic Boissay, Martin Brown, Peter Hoerdahl, Bo Honoré, Cathérine Koch, Ulf Lewrick, Pius Matter, Cyril Monnet, Davy Reinhard, Jean-Paul Renne, Bertrand Rime, Mark Watson, and the members of the financial stability unit of the Swiss National Bank. We would also like to thank the participants at the seminar of the Bank for International Settlements (BIS), the 2016 Annual Congress of the Swiss Society of Economics and Statistics, the Brownbag Seminar Series of the Swiss National Bank (SNB), and the Macroworkshop and Research Days of the University of Lausanne. We thank Elio Bolliger for his excellent research assistance. Any errors and/or omissions are solely our own. 


\section{Introduction}

Banks are exposed to adverse movements in interest rates because on average, rates on their long, fixed-term assets are locked in for longer than rates on their liabilities. When the general level of interest rates rises, banks typically experience a loss in economic value because the value of assets decreases more than the value of liabilities.

One important question in that context is the extent to which realized interest rate risk exposure - i.e., the gain or loss in a bank's economic capital attributable to movements in interest rates - affects bank lending. This question is particularly relevant in the current environment of prolonged low nominal interest rates in which banks have substantially increased their interest risk exposure (Turner, 2013; SNB, 2014, 2015). For instance, findings by Hanson and Stein (2015) suggest that as nominal interest rates declined, banks have rebalanced their asset holdings toward longer maturities to prevent their portfolios' overall yield from decreasing too much.

The theoretical literature on the transmission of monetary policy postulates that interest rate risk exposure makes bank lending more sensitive to changes in nominal interest rates (Van den Heuvel, 2002, 2007). The postulated mechanism contains the following intuition: If nominal interest rates rise, the resulting loss depletes a bank's economic capital and brings it closer to regulatory or market requirements. In such a situation, the bank's ability to restore its required capital level by issuing new equity is limited because asymmetric information between existing and potential new shareholders makes equity issuances costly (Myers and Majluf, 1984; Kashyap and Stein, 1995; Myers, 2001). Consequently, the bank reduces its lending to remain in compliance with capital requirements imposed by regulators or market participants.

Empirically testing how realized interest rate risk exposure affects bank lending is difficult for two reasons. First, necessary information about interest rate sensitive balance sheet positions and the corresponding repricing maturities is often unavailable. Second, detailed information about the positions used for hedging against interest rate risk is typically not publicly available. Therefore, constructing a measure of individual interest rate risk exposure net of hedging is often infeasible based on publicly available information.

In this paper, we address these issues by exploiting a quarterly panel data set comprising supervisory information on Swiss banks between 2001Q2 and 2013Q3. Our sample comprises domestically focused commercial banks whose business model results in interest rate risk acting as a major risk factor. The data set provides us with an individual measure of interest rate risk exposure that directly relies on each bank's repricing maturity profile. In a supervisory survey, each bank reports its interest rate-sensitive cash flows separated by their repricing maturities, i.e., the remaining time until the interest rate on the underlying position is reset. The repricing mismatch implied by these cash flows yields the individual measure of interest rate risk exposure. This measure corresponds to the adjustment in the bank's economic value in response to a permanent 1 percentage point (pp) change in nominal interest rates over 
all maturities. One major advantage of this measure is that it reflects individual interest rate risk exposure net of hedging because the bank's reported cash flows consider eventual hedging positions.

We apply a dynamic panel data model that relates bank loan growth to interest rate risk exposure and various individual and macroeconomic control variables. The model, inspired by Kashyap and Stein $(1995,2000)$ and Gambacorta and Mistrulli (2004), enables us to estimate the most important channels through which bank loan growth responds to changes in nominal interest rates. It also allows us to estimate the sensitivity of this response to individual interest rate risk exposure.

The analysis yields two main results. First, changes in economic capital, as measured by realized interest rate risk exposure, affect bank lending. The estimated effects of a given shock in interest rates are initially small and not statistically significant but increase over the next four quarters, eventually becoming highly significant. For instance, in response to a permanent $1 \mathrm{pp}$ increase in nominal interest rates, the average bank in 2013Q3 would, ceteris paribus, reduce its predicted quarter-on-quarter loan growth rate by 46 basis points (bp) immediately after the shock and reduce its cumulative loan growth after one year by approximately $300 \mathrm{bp}$. The impact of an interest rate shock on bank lending significantly depends on individual exposure to interest rate risk. The higher a bank's exposure to interest rate risk, the higher the impact of an interest rate shock on its lending. For example, if the average bank's interest rate risk exposure ceteris paribus corresponded to the 1st (9th) decile instead of the average, it would reduce its quarter-on-quarter loan growth by 37 (55) bp immediately after the shock and reduce its cumulative loan growth after one year by approximately 260 (340) bp. These estimated effects are also economically significant both in light of the recent increase in interest rate risk exposure and in comparison to the average quarter-on-quarter loan growth rate, which was approximately $95 \mathrm{bp}$ over the sample, corresponding to an annualized growth rate of approximately $385 \mathrm{bp}$.

Second, bank lending appears to be mainly driven by capital rather than liquidity. In contrast to changes in economic capital caused by realized interest rate risk exposure, we find no evidence that changes in excess liquidity significantly affect bank lending. This result may reflect that liquidity buffers were large and that most banks did not experience any strains on liquidity over the sample period.

The results are relevant for policy. They indicate that considering the level of the banks' exposure to interest rate risk is relevant for understanding how changes in interest rates affect bank loan growth. In particular, our results suggest that individual bank loan growth may have become more sensitive to changes in interest rates than was the case prior to the recent increase in interest rate risk exposure. Although our estimates cannot be directly aggregated because they are based on individual data and do not consider eventual general equilibrium effects, they suggest that a given upward shock in nominal interest rates would likely have a bigger impact on bank lending than in past periods in which banks' interest rate risk exposure was lower. Moreover, banks' heterogeneity in interest rate risk exposure implies that even a relatively 
small shock can cause sizable economic losses at the most exposed institutions, potentially leading them to largely curb their lending. Therefore, changes in nominal interest rates could have redistributive effects; especially if banks' interest rate risk exposure varies across regions. Finally, the finding that capital matters more for bank loan growth than liquidity is consistent with the observations of Kishan and Opiela (2000, 2006), i.e., that a higher capitalized banking system can better shield its creditors from shocks in interest rates. The question of how these results can be integrated into policy making naturally follows from our analysis but is beyond the scope of this paper.

This paper is primarily related to the empirical literature on bank lending. Its empirical strategy is similar to that of a seminal paper by Kashyap and Stein (2000) that analyzes the various transmission channels of monetary policy via the banking system. Bichsel and Perrez (2005) investigate how monetary policy affected bank lending in Switzerland between 1996 and 2002. However, they do not explicitly consider interest rate risk exposure and focus on the relative importance of capital and liquidity for bank lending. Gambacorta and Mistrulli (2004) analyze the transmission of monetary policy in Italy between 1992 and 2001. Unlike the previous two papers mentioned, Gambacorta and Mistrulli (2004) include a supervisory measure of interest rate risk exposure. Similar to our paper, Gambacorta and Mistrulli (2004) measure of interest rate risk exposure is based on each bank's repricing maturity profile. However, their paper does not adopt an economic value perspective: future cash flows are not discounted to their present value. Even though Gambacorta and Mistrulli (2004) apply an estimator that differs from ours, they also find that realized interest rate risk exposure has a strong effect on bank lending.

More recent work that is closely related to ours is by Landier, Sraer and Thesmar (2015). They estimate the impact of interest rate risk exposure of US bank holding companies on the transmission of monetary policy between 1986 and 2011. However, their measure of interest rate risk exposure has a different focus than our measure: whereas our measure is based on a supervisory survey and considers each bank's entire maturity profile, their measure is based on publicly available data on each bank's income statement and solely considers assets and liabilities that reprice within one year. Their measure is a good proxy for the maturity mismatch under the assumption that on average, assets and liabilities that reprice after more than a year have a similar duration. In contrast to our results, Landier et al. (2015)'s findings imply that on average, banks would benefit from increasing interest rates because on average, their income gaps for maturities up to one year are positive.

The remainder of the paper is organized as follows. Section 2 gives an overview of the structure of the Swiss banking system and later describes the sample and variables we use in the econometric analysis. Section 3 outlines the econometric analysis. It provides background information on the main channels though which nominal interest rates can affect bank lending. Subsequently, it explains the empirical model that we apply to identify how individual interest rate risk exposure affects bank lending. Section 4 interprets the results and presents some 
robustness checks. Finally, section 5 concludes. 


\section{Data and summary statistics}

This section first provides stylized facts about the Swiss banking system. Subsequently, it discusses the sample and the variables that we use in the econometric analysis.

\subsection{Stylized facts on the Swiss banking system}

Table 1 summarizes the structure of the Swiss banking system, which provides an ideal laboratory for analyzing the effects of realized interest rate risk on bank lending. By the end of 2012, Switzerland had 297 banks with total assets of approximately 3.597 trillion CHF. $^{1}$

Table 1: Summary Statistics on the Swiss Banking System in 2012Q4

\begin{tabular}{|c|c|c|c|c|c|}
\hline Category & $\begin{array}{c}\text { Number of } \\
\text { Banks }\end{array}$ & $\begin{array}{l}\text { Domestic Client } \\
\text { Loans }\end{array}$ & $\begin{array}{c}\text { Domestic Mortgage } \\
\text { Loans }\end{array}$ & $\begin{array}{c}\text { Total Domestic } \\
\text { Loans }\end{array}$ & $\begin{array}{l}\text { Total } \\
\text { Assets }\end{array}$ \\
\hline \multicolumn{6}{|l|}{ Domestically Focused Banks: } \\
\hline Cantonal Banks & 24 & $47^{\prime} 718$ & $289^{\prime} 823$ & $337^{\prime} 541$ & $482 ’ 278$ \\
\hline Regional and Savings Banks & 40 & $6 ’ 588$ & $81 ’ 712$ & $88^{\prime} 300$ & $102^{\prime} 530$ \\
\hline Cooperative of Raiffeisen Banks & 1 & 7'605 & $135^{\prime} 599$ & $143 ’ 204$ & $164^{\prime} 670$ \\
\hline Other Domestically Focused Banks & 2 & 4’137 & $41 ’ 382$ & $45^{\prime} 519$ & $53 ’ 345$ \\
\hline Big Banks & 2 & $62 ’ 395$ & $252 ’ 147$ & $314^{\prime} 542$ & $2^{\prime} 183^{\prime} 512$ \\
\hline Other Banks & 228 & $37^{\prime} 400$ & $33^{\prime} 759$ & $71 ' 159$ & $610^{\prime} 706$ \\
\hline Banking System Total & 297 & $165^{\prime} 843$ & $834^{\prime} 422$ & 1’000’265 & 3'597’041 \\
\hline Share of Domestically Focused Banks & & $40 \%$ & $66 \%$ & $61 \%$ & $22 \%$ \\
\hline
\end{tabular}

Notes : Figures are in millions of Swiss Francs. The category 'total domestic loans' includes all loans made to the real sector. The category 'domestic client loans' represents the difference between 'total domestic loans' and 'domestic mortgage loans' and mostly contains commercial loans. The category 'domestically focused banks' comprises all banks excluding the two big banks that have (i) a share of domestic loans to total assets that is greater than $50 \%$ and (ii) a volume of domestic loans of at least 280 million Swiss Francs. The term 'domestic' means that the borrowers of client loans are domiciled in Switzerland, and the real estates serving as collateral for mortgage loans are located in Switzerland.

Source : SNB website, annual reports for big bank assets and internal data.

The different types of banks fit into three main categories. The first category comprises the domestically focused banks. This category contains all retail banks that provide domestic loans to the real sector of at least 280 million CHF, composing at least half of such banks' total assets. In 2012Q4, there were 24 mostly state-owned cantonal banks, 40 regional and savings banks, the cooperative of Raiffeisen banks, and 2 other domestically focused banks in the first category. The second main category consists of two big banks, UBS and Credit Suisse. As internationally active universal banks, UBS and Credit Suisse offer a broad range of services. The third main category, labeled "other banks", is composed of a heterogeneous group of mostly small banks specializing in various business models such as asset management, brokerage, and trade financing.

The Swiss banking system is highly concentrated. The two big banks account for just over

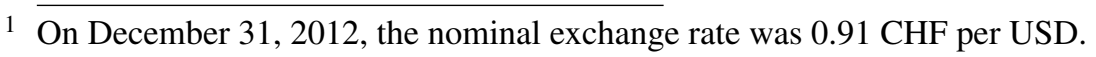


half of the system's total assets. Even though roughly two-thirds of their business is abroad and a large proportion of their balance sheets consists of financial assets, the two big banks still reached a combined market share of approximately $31 \%$ in the market for domestic loans to the real sector in 2012Q4. However, the domestically focused banks are the most important providers of domestic loans to the real sector, with a combined market share of $61 \%$ in $2012 \mathrm{Q} 4$. The remaining 228 banks play only a minor role in domestic lending to the real sector and claimed a combined market share of $8 \%$ in $2012 \mathrm{Q} 4$.

\subsection{Sample and variables for the empirical analysis}

For the empirical analysis, we build a data set that covers the period between 2001Q2 and 2013Q3 and includes quarterly information about bank lending, exposure to interest rate risk, capital, liquidity, and balance sheet size collected from periodic surveys conducted by the Swiss National Bank (SNB). ${ }^{2}$ Our sample represents an ideal laboratory of 67 domestically focused commercial banks. The main reason for using this sample is that the studied banks are predominantly active in the interest income business (mostly in Swiss francs). Net interest income represents a large part (an average of approximately 70\%) of their earnings. Because of their business model, interest rate risk is a major risk for these banks. We complement the information about bank-level data with macroeconomic variables such as short- and long-term interest rates, inflation, real GDP growth, and nominal house price growth.

\subsubsection{Exposure to interest rate risk}

Interest rate changes affect the underlying economic value of a bank's assets, liabilities and offbalance sheet instruments because of adjustments in the discount rates used to determine the present value of these categories' future cash flows. Consequently, a bank's economic capital the difference between the present value of its incoming cash flows and its outgoing cash flows - is affected by nominal interest rate movements.

Our measure of interest rate risk exposure is based on data collected from a comprehensive supervisory survey conducted by the SNB on behalf of Switzerland's microprudential supervisor, the Swiss Financial Markets Supervisory Authority (FINMA). The survey provides detailed information about each bank's repricing maturity profile $i$ in each quarter $t$. Each quarter, banks report all significant notional and interest rate cash flows arising from interest rate sensitive positions both in their banking book and in their securities and precious metal trading portfolio. Each cash flow is allocated to one of 18 time bands according to its repricing maturity, which is defined in this context as the remaining time period until the interest rate on a position is reset. $^{3}$ Positions are differentiated into three main categories according to the nature of their

2 A small number of banks only report certain variables biannually. We linearly interpolate those variables to obtain quarterly observations.

3 The 18 bands are of different lengths. There are 7 time bands for repricing below 1 year: up to 1 day, 1 day to 1 month, 1 month to 2 months, 2 months to 3 months, 3 months to 6 months, 6 months to 9 months and 9 months to 1 year. There are 9 yearly time bands for maturities between 1 and 10 years. The longest time bands are 10 to 15 
interest rate repricing maturities. ${ }^{4}$ The first contains all positions with a defined interest rate repricing maturity, for example, fixed-rate mortgages. ${ }^{5}$ The second category covers positions with undefined interest rate repricing maturities such as sight claims, claims against customers and variable rate mortgage claims on the assets side and sight liabilities and savings deposits on the liabilities side. The third category regroups each bank's remaining position without or with arbitrary interest rate repricing maturities. Cash flows of positions falling in the last two categories are reported according to the banks' internal assumptions on interest rate repricing maturities.

For each of the 18 time bands, $m$, the difference between incoming and outgoing cash flows determines the net cash flow, $C F(m)_{i t}$. Based on these net cash flows, the bank's interest rate risk exposure, $\rho_{i t}$, is given by:

$$
\rho_{i t}=\sum_{m=1}^{18} C F(m)_{i t}\left[D F(m)_{t}^{+1 p p}-D F(m)_{t}\right] \text {, }
$$

where $D F(m)_{t}$ is the discount factor using the relevant risk-free interest rates for maturity $m$ at time $t$, and $D F(m)_{t}^{+1 p p}$ is the hypothetical discount factor following a $1 \mathrm{pp}$ increase in interest rates across all maturities. A positive net cash flow in time band $m$ leads to a reduction in the bank's economic capital when interest rates increase because for a given time band $m$, the value of assets decreases more than the value of liabilities. Therefore, a bank that typically extends loans with a repricing maturity exceeding that of its liabilities will experience a decrease in the value of its equity when interest rates increase. Note that $\rho_{i t}$ reflects the bank's interest rate risk exposure net of hedging because $C F(m)_{i t}$ comprises all cash flows, including those from linear hedging positions.

The measure of individual interest rate risk exposure, $\rho_{i t}$, corresponds to the approximate change in bank $i$ 's economic capital that would be realized per pp when the risk-free nominal yield curve shifts upward. Therefore, a parallel shift of the yield curve by $\Delta i_{t+1}$ pp changes bank $i$ 's economic capital by approximately $\rho_{i t} \times \Delta i_{t+1}$ CHF. To make the realized interest rate risk exposure comparable across banks, we express it as a fraction of eligible capital,

$$
\frac{\rho_{i t} \times \Delta i_{t+1}}{E l i g C_{i t}}
$$

Figure 1 illustrates how Swiss banks' interest rate risk exposure evolved between 2001Q2 and 2013Q3. The orange line corresponds to the average realized interest rate risk exposure years and above 15 years.

4 A fourth category covers eligible capital, mostly made up of equity. We do not consider the cash flows of these positions because we want to precisely measure the changes in economic capital.

5 A 10 year fixed-rate mortgage with yearly interest payments (without pre-payment option) issued five years and one day before the current date is reported in the survey as follows: the notional cash flow and the most recent interest cash flow are reported in a time band corresponding to the residual maturity - i.e., 4 to 5 years -and the remaining yearly interest cash flows in four distinct time bands - i.e., 9 months to 1 year, 1 to 2 years, 2 to 3 years and 3 to 4 years. 
Figure 1: Interest rate risk exposure of Swiss banks

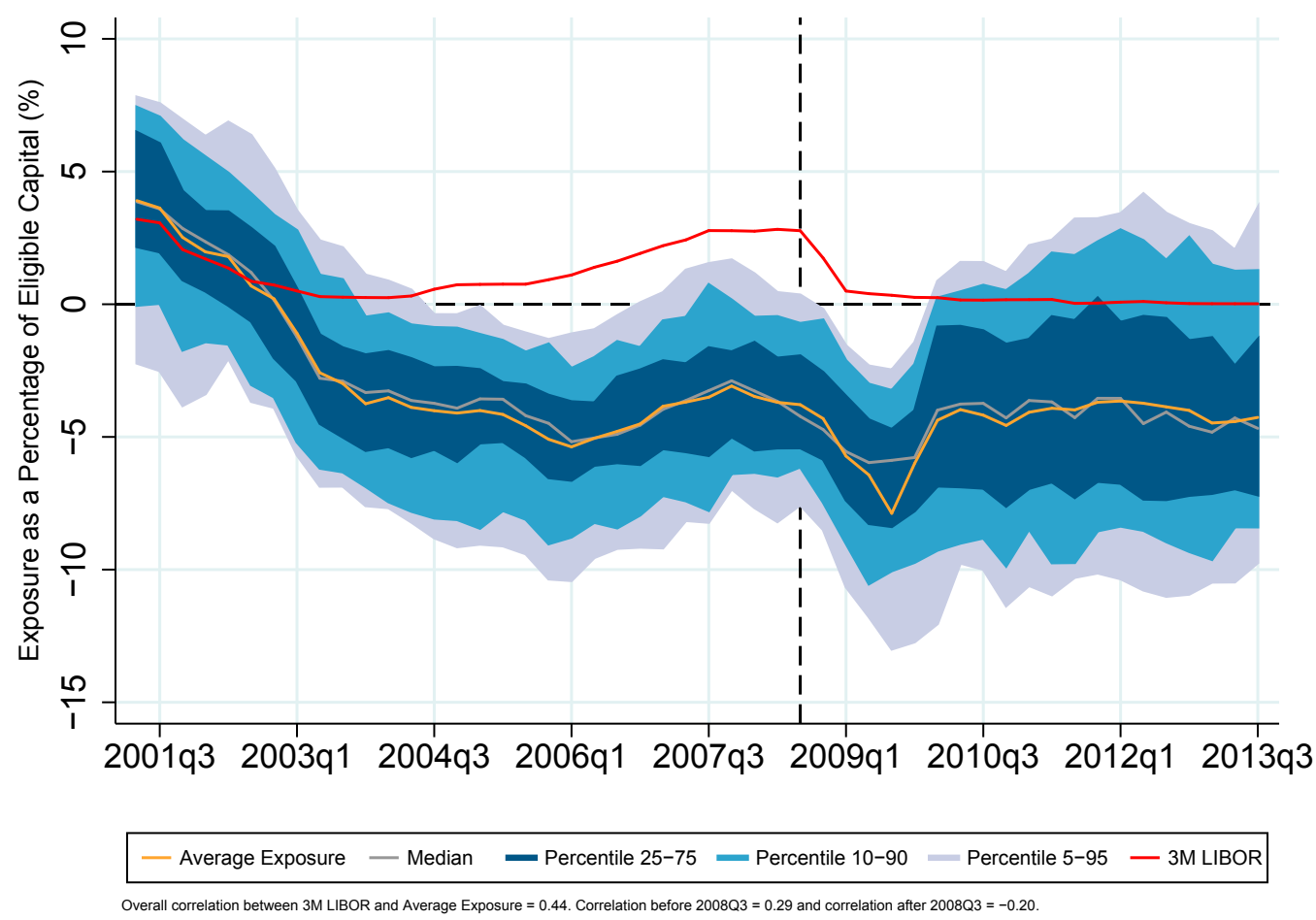

as a fraction of eligible capital that would have occurred in response to a $1 \mathrm{pp}$ upward shift in nominal interest rates. The shaded areas represent the various interpercentile ranges, along with median levels (grey line), of interest rate risk exposure.

Swiss banks substantially increased their interest rate risk exposure over the sample period. In 2001Q2. On average, they experienced an economic gain amounting to $3.75 \%$ of eligible capital if nominal interest rates increased by 1 pp: i.e., on average their liabilities had longer maturities than their assets. However, shortly afterward, they began to increase their interest rate risk exposure. By the end of 2008, they incurred an average economic loss equivalent to approximately $4.25 \%$ of eligible capital in response to a $1 \mathrm{pp}$ increase in nominal interest rates. Since then, their interest rate risk exposure has been roughly stable on average but has become more heterogeneous.

Nominal interest rates, represented by the 3 month LIBOR in red, also varied substantially between 2001Q2 and 2013Q3. The overall correlation between the 3 month LIBOR and average bank interest rate risk exposure is positive. Note that the correlation before 2008Q3 is positive but negative after 2008Q3. Thus, nominal interest rates and interest rate risk exposure do not comove perfectly, thus helping us identify the effect of interest rate risk exposure on bank loan growth.

\subsubsection{Individual bank characteristics and macroeconomic variables}

Table 2 presents summary statistics of all of the variables in the sample. Its upper panel contains individual bank characteristics, whereas its lower panel exhibits variables that proxy for the 
macroeconomic environment and are common to all banks.

Table 2: Sample Summary Statistics

\begin{tabular}{lcccccc}
\hline \hline Variable & Unit & Obs. & Mean & Std. Dev & Min & Max \\
\hline Individual Bank Variables: & & & & & & \\
Realized Interest Rate Risk & (Fraction) & 3182 & -0.002 & 0.017 & -0.115 & 0.150 \\
(fraction of eligible capital) & & & & & & \\
Domestic Loan Growth Rate & (QoQ \%) & 3278 & 0.942 & 1.034 & -3.755 & 6.028 \\
Excess Capital & (Fraction) & 3293 & 0.540 & 0.342 & -0.872 & 2.043 \\
Normalized Excess Capital & - & 3293 & 0.000 & 0.342 & -1.411 & 1.504 \\
Excess Liquidity & (Fraction) & 3295 & 0.857 & 0.683 & -0.425 & 5.751 \\
Normalized Excess Liquidity & - & 3295 & 0.000 & 0.683 & -1.282 & 4.894 \\
Log of Total Assets & (Log) & 3295 & 14.79 & 1.460 & 12.452 & 19.07 \\
Normalized Log of Total Assets & - & 3295 & 0.000 & 1.458 & -2.191 & 4.037 \\
\hline Macroeconomic Variables: & & & & & & \\
$\Delta$ Short-term interest rate & & & & & & \\
$\Delta$ Long-term interest rate & (p.p.) & 50 & -0.068 & 0.312 & -1.245 & 0.350 \\
Inflation Rate & (p.p.) & 50 & -0.046 & 0.251 & -0.708 & 0.464 \\
Real GDP Growth Rate & (YoY \%) & 50 & 0.621 & 0.876 & -1.019 & 2.975 \\
Nominal Housing Price Growth Rate & (YoY \%) & 50 & 1.687 & 1.767 & -3.138 & 4.089 \\
\hline \hline
\end{tabular}

Notes : Loan growth is a non-annualised quarter on quarter growth rate. Excess measures are defined as eligible minus required divided by required. Inflation and real GDP both represent annualised year on year quarterly rates, i.e. percentage change with corresponding quarter in the previous year. The sample period spans from 2001Q2 until 2013Q3 at a quarterly frequency. The panel data set is mildly unbalanced.

The most important individual bank characteristic is the realized interest rate risk exposure as a fraction of eligible capital. We calculate it using equation (2) and proxy for the change in nominal interest rates, $\Delta i_{t+1}$, by the change in the 3 month LIBOR, $\Delta i_{t+1}^{3 M}$. We later show that our results remain robust if we use an alternative proxy for the change in nominal interest rates that also considers long term interest rates. Over the sample period, the realized change in economic capital caused by interest rate risk exposure was close to zero on average but varied substantially over time and across banks.

The other individual bank characteristics are total domestic loans, excess capital, liquidity, and total assets. Total domestic loans are made up of domestic client and mortgage loans. They allow us to calculate the quarter-on-quarter bank loan growth rate, which was approximately $0.95 \%$ on average over the sample period, or $3.80 \%$ when annualized. Excess capital and liquidity correspond to the eligible minus the required amounts. To make them comparable across banks, we report them as fractions of the required amounts. On average, capitalization and liquidity exceeded the requirements by $54 \%$ and $86 \%$, respectively. This high level of excess liquidity reflects that most banks did not experience any strains on liquidity during the sample period. We proxy for bank size by the log of total assets, which was 14.79 on average. 
To make excess capital, excess liquidity, and bank size easier to interpret in the econometric analysis, we apply the following normalizations. We center excess capital and excess liquidity on the entire sample mean so that interaction terms involving these variables have an interpretation with respect to the average bank in the sample. Similarly, we center bank size on the sample average in each period to address its trending nature. We also account for both outliers and market entries and exits in the sample. For more detailed information about the handling of outliers, the normalizations, and the treatment of market entries and exits, please refer to appendix A.1.

Finally, to proxy for the macroeconomic environment, we add the 3 month LIBOR on CHF, the 10 year government bond yield, the inflation rate measured by the general consumer price index, the real GDP growth rate, and the nominal house price growth rate to the sample. 


\section{Empirical analysis}

This section first reviews the conceptual background that provides the basis for the empirical model. Second, it describes the specification of the empirical model that allows us to identify the effects of interest rate risk exposure on bank lending.

\subsection{Conceptual background}

In the empirical analysis we focus on isolating the effects of interest rate risk exposure on bank lending. To do so, we must partial out the other main channels through which changes in nominal interest rate can affect bank lending.

A growing body of theoretical literature on the effects of monetary policy, originating from Bernanke and Blinder (1988), has analyzed market imperfections that give rise to three main channels through which changes in nominal interest rates can affect bank lending. A change in nominal interest rates can filter through: (i) the Bank Capital Channel (BCC), (ii) the Bank Lending Channel (BLC), and (iii) the Balance Sheet Channel (BSC). Each of these channels relies on distinct market imperfections that are amplified by individual bank or borrower characteristics.

We focus on the BCC, which describes how a bank's interest rate risk exposure provides the basis for interest rate changes to shift its lending. The wider the repricing mismatch, the more exposed the bank is to interest rate risk, thus increasing its resulting loss in capital when nominal interest rates rise and eventually decreasing its lending. Van den Heuvel (2007) develops a detailed model of a bank's asset and liability management that incorporates capital requirements and an imperfect market assumption for bank capital. In this model, the bank exhibits a maturity mismatch in its balance sheet - i.e., it relies on short-term funding to finance long-term assets - and holds a capital buffer in excess of regulatory or market requirements. If nominal interest rates rise, the bank experiences a loss in capital because the interest rates on its shortterm funding adjust more rapidly than on its long-term assets. This loss depletes the bank's capital buffer and brings it closer to regulatory or market capital requirements. In this situation, the bank typically does not issue new equity: equity issuances are costly because of asymmetric information between the bank's existing shareholders and potential future shareholders (see e.g. Myers and Majluf, 1984; Kashyap and Stein, 1995; Myers, 2001). The intuition is that existing shareholders and the bank's management know the economic value of the bank's assets and only agree on issuing new equity if the bank's actual share price is overvalued. However, potential future shareholders anticipate this reasoning and are only willing to invest in newly issued equity at large discounts. Cornett and Tehranian (1994) show empirically that issuing new equity can be costly. Consequently, instead of issuing new equity, the bank will decrease its loan supply to remain in compliance with the capital requirements imposed by regulators or market participants. Empirical work on Italian banks by Gambacorta and Mistrulli (2004) confirms that a wider maturity mismatch leads to a stronger reaction of bank lending to changes 
in nominal interest rates.

In contrast, the BLC describes how a bank's liquidity levels determine how its loan schedule will withstand changes to the banking system's available reserves once interest rates change. Bernanke and Blinder (1988) show with a standard IS/LM model that the Fed's draining of reserves and therefore insured deposits reduces the banking system's loanable funds, ultimately decreasing the supply of bank loans. The BLC relies on the market imperfection that insured deposits carry artificially low interest rates compared to other sources of short-term funding that are not covered by deposit insurance. Thus, if a bank has to replace an outflow of insured deposits by other sources of uninsured short-term funding, its funding costs increase and therefore, the bank reduces its loan supply. Kashyap and Stein $(1995,2000)$ provide empirical evidence for the BLC. In particular, they find that changes in monetary policy matter more for lending by small, less liquid banks.

Finally, the BSC by Bernanke and Gertler (1995) captures how raising nominal interest rates affects bank lending via borrowers' altered creditworthiness. Borrowers' creditworthiness deteriorates because of increased interest payments on outstanding variable rate debt. Similarly, increasing interest rates are usually associated with decreasing asset value that erodes the value of the borrowers' collateral. Consequently, bank lending to these borrowers typically decreases as the agency costs associated with monitoring or screening increase. Jiménez, Ongena, Peydró and Saurina (2012) exploit an extensive data set on the universe of commercial loans granted by all banks in Spain to study how bank lending to firms is affected by monetary policy. One main result is that firms with weaker balance sheets and shorter creditworthy track records can rely less on external financing.

In sum, both the BCC and BLC depend on individual bank characteristics. In contrast, similar to loan demand, the extent of the BSC primarily relies on individual borrower characteristics. Therefore, our empirical strategy aims at isolating the BCC - our focus - along with the BLC. In contrast, it treats the BSC together with loan demand as one of the remaining components of loan growth that we cannot further disentangle explicitly because we do not observe individual borrower characteristics.

\subsection{Empirical model}

We apply a dynamic panel data model of bank loan growth inspired by Kashyap and Stein $(1995,2000)$ and Gambacorta and Mistrulli (2004). This model allows us to estimate how 
interest rate changes affect bank loan growth. We estimate the following specification:

$$
\begin{aligned}
\Delta \ln L_{i t} & =\alpha \Delta \ln L_{i t-1}+\sum_{s=0}^{4} \beta_{1, s}\left(\frac{\rho_{i t-1} \times \Delta i_{t}^{3 M}}{E l i g C_{i t-1}}\right)_{i t-s} \\
& +\sum_{s=0}^{4} \beta_{2, s} B_{i t-1} \times \Delta i_{t-s}^{3 M}+\sum_{s=0}^{4} \beta_{3, s} C_{i t-1} \times \Delta i_{t-s}^{3 M} \\
& +\sum_{s=0}^{4} \beta_{4, s} \Delta i_{t-s}^{3 M}+\sum_{s=0}^{4} \beta_{5, s} \Delta i_{t-s}^{10 Y} \\
& +\beta_{6} B_{i t-1}+\beta_{7} C_{i t-1}+\beta_{8} S_{i t-1}+\sum_{s=0}^{4} \beta_{9, s} C_{i t-1} \times y_{t-s} \\
& +\sum_{s=0}^{4} \beta_{10, s} S_{i t-1} \times \Delta i_{t-s}^{3 M}+\sum_{s=0}^{4} \beta_{11, s} \Delta h p_{t-s} \\
& +\sum_{s=0}^{4} \beta_{12, s} y_{t-s}+\sum_{s=0}^{4} \beta_{13, s} \pi_{t-s}+\sum_{s=2}^{4} \theta_{s}+\mu_{i}+\epsilon_{i t},
\end{aligned}
$$

with $i=1, \ldots, N$ banks and $t=5, \ldots, T$ quarters. The dependent variable, $\Delta \ln L_{i t}$, is the first difference of bank $i$ 's log loan volume in quarter $t$. Therefore, the dependent variable can be interpreted as the quarter-on-quarter loan growth rate. Individual bank characteristics are all lagged by one quarter to avoid simultaneity problems. Next, we explain the roles of the different regressors.

The model features one lag of the dependent variable among the regressors. ${ }^{6}$ This feature has two benefits. First, the lagged dependent variable controls for unobserved characteristics of bank $i$ 's lending in the previous periods that impact loan growth in the current period. Second, it allows for the model's dynamic response, which enables us to study how the effects of an interest rate change on bank loan growth evolve over time.

The parameters $\beta_{1, s}$ identify the effect of realized interest rate risk exposure as a fraction of eligible capital. Even though the change in economic capital has no immediate P\&L effect on regulatory capital, because it represents a change in the present value of future cash flows, the bank is likely to anticipate the resulting future P\&L effects and adjust its loan supply with the new information. This adjustment is in line with the BCC literature, which postulates that a bank losing part of its capital will curb its lending because its capitalization becomes closer to limits imposed by regulators or market participants. Therefore, we expect losses in economic capital attributable to realized interest rate risk exposure to have a negative effect on bank lending. This also implies that loan growth of more highly exposed banks should be more sensitive to changes in nominal interest rates.

The interaction terms of normalized excess liquidity, $B_{i t-1} \times \Delta i_{t-s}^{3 M}$, and normalized excess

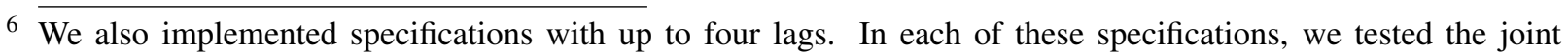
significance of the additional lags. In all cases, the additional lags were never jointly significant. Furthermore, partial autocorrelation analyses suggest that the first lag is the most relevant. 
capital, $C_{i t-1} \times \Delta i_{t-s}^{3 M}$, with the three month LIBOR, $\Delta i_{t}^{3 M}$, have three interpretations. The first interaction term controls for the notion that the loan supply of banks with larger liquidity buffers should be more robust to a given change in nominal interest rates because these banks can cope longer with liquidity outflows before they need to tap into more expensive sources of uninsured short-term funding. The interpretation of the second interaction term, however, is two-fold. On the one hand, it captures that the "lemon premium," - i.e., the spread between the costs of insured deposits versus other sources of uninsured short-term funding - is lower for more highly capitalized banks. On the other hand, an increase in interest rates generally worsens the borrowers' financial position and can result in higher future defaults, which then must be absorbed by the bank's capital. If banks anticipate the higher future default rates, loan supply at more highly capitalized banks will react less than at lower capitalized banks because regulatory capital requirements are less binding for more highly capitalized banks. The first two interpretations correspond to the BLC, whereas the third corresponds to the BSC. In sum, we expect both of these interaction terms to have a positive effect on bank loan growth.

The specification also includes changes in the three month LIBOR, $\Delta i_{t}^{3 M}$, which proxies for movements in short-term rates along with changes in the 10 year government bond yield, $\Delta i_{t}^{10 Y}$, which proxies for movements in long-term rates. The combined inclusion of these proxies for short- and long-term interest rate movements is useful given that our measure of interest rate risk exposure considers a general change in nominal interest rates over all maturities.

We further include individual bank characteristics that account for bank-specific factors that lead to heterogeneity in loan growth. First, the effect of normalized excess liquidity, $B_{i t-1}$, on loan growth is ambiguous. Large stocks of liquidity may result from management moving to buffer up liquidity, which, all else being equal, mechanically decreases loan supply. Alternatively, large liquidity buffers may also provide a pool of loan funding. Second, the effect of normalized excess capital, $C_{i t-1}$, on loan growth is also ambiguous, for similar reasons. On the one hand, we expect prudent management to be associated with high capital buffers and low loan growth. On the other hand, large capital buffers could help expand loan growth by making uninsured short-term funding cheaper. Finally, normalized size, $S_{i t-1}$, most likely has a negative coefficient because a given absolute increase in loan volume mechanically has a smaller effect on the loan growth rate of large banks because of the larger size of the existing loan base.

The specification additionally incorporates regressors that proxy for the economic environment. We expect the interaction between normalized excess capital and the real GDP growth rate, $C_{i t-1} \times y_{t-s}$, to have a negative effect on loan growth because more solvent banks are better positioned to withstand economic downturns, resulting in a more stable credit supply. The literature typically explains this by the fact that more highly capitalized banks are more risk averse and lend ex ante to borrowers with lower probabilities of default (see for example Kwan and Eisenbeis (1997)). The interaction between normalized size and the three month LIBOR rate, $S_{i t-1} \times \Delta i_{t-s}^{3 M}$, controls for the possibility that bigger banks may be more resilient to changes in interest rates. The changes in nominal house prices, $\Delta h p_{t}$, proxy for the impact on 
borrower financial positions. The real GDP growth rate, $y_{t}$, captures changes in loan demand caused by the business cycle, whereas the CPI inflation rate, $\pi_{t}$, explains the part of loan growth that is simply attributable to larger nominal loan values.

We also allow for individual bank fixed effects, $\mu_{i}$, which remain invariant over time and are unique to bank $i$. These individual bank fixed effects absorb any potential effects of timeinvariant individual characteristics of the banks that influence loan growth. Finally, we include quarter dummies, $\theta_{j}$, to capture seasonality in bank loan growth. 


\section{Results}

This section first presents evidence on the importance of the different channels through which changes in nominal interest rates affect bank loan growth. Subsequently, it discusses the impact of realized interest rate risk on bank loan growth. Finally, it summarizes the results of three robustness checks.

\subsection{Effect of interest rate risk on bank loan growth}

Table 3 exhibits the estimated effects of the different channels through which a change in nominal interest rates may affect bank loan growth. ${ }^{7}$ For a given change in nominal interest rates, $\Delta i$, the first column shows the immediate effects, whereas the second column shows the longrun effects under the assumption that no adjustment occurs in other variables apart from bank loan growth. The long-run estimates can be interpreted as approximate cumulative effects over the next year because the weights of future periods decline at a geometric rate and any period after four quarters in the future has a negligible weight. ${ }^{8}$

7 For a table containing all estimated coefficients and a discussion of how we chose the appropriate estimator, please refer to appendix A.3. Our results are based on the within-groups transformation estimation, which can be found in Table A3 in appendix A.3.

8 The long-run effect of a set of coefficients is given by $\frac{\sum_{s=0}^{4} \hat{\beta}_{j, s}}{(1-\hat{\alpha})}$. Versions with further lagged dependent variables take the following form: $\frac{\sum_{s=0}^{4} \hat{\beta}_{j, s}}{\left(1-\sum_{s=1}^{r} \hat{\alpha}_{s}\right)}$, where $r$ is the number of lags. We approximate the effects on annual loan growth by the predicted cumulative effects of our model over the four quarters that follow an interest rate shock because the weights of future periods decline at a geometric rate and any period after four quarters in the future has an almost negligible weight. 
Table 3: Immediate vs. Long-run Effects

\begin{tabular}{lcc}
\hline \hline Variables & Immediate & Long-Run \\
\hline Realized Interest Rate Risk & 1.94 & $8.96^{* * *}$ \\
(fraction of eligible capital) & $(2.11)$ & $(3.26)$ \\
Normalized Excess Liquidity $\times \Delta i^{3 M}$ & -0.07 & -0.06 \\
& $(0.11)$ & $(0.14)$ \\
Normalized Excess Capital $\times \Delta i^{3 M}$ & -0.16 & -0.03 \\
& $(0.28)$ & $(0.90)$ \\
Normalized Size $\times \Delta i^{3 M}$ & -0.08 & -0.06 \\
& $(0.05)$ & $(0.08)$ \\
$\Delta$ Short-term interest rate $\left(\Delta i^{3 M}\right)$ & $-0.46^{* * *}$ & $-2.54^{* * *}$ \\
$\Delta$ Long-term interest rate $\left(\Delta i^{10 Y}\right)$ & $(0.16)$ & $(0.48)$ \\
& 0.08 & -0.18 \\
\hline \hline
\end{tabular}

Notes : Dependent variable is the first difference of log quarterly loan volume, i.e. approximately the quarter on quarter loan growth rate. Estimates using the Within Groups transformation in Table A3. All standard errors, in parentheses, are cluster robust at a bank level. Immediate effect standard errors are simply regression estimates. Long-run effect standard errors are calculated using the delta-method. The long-run effects work under the assumption that no adjustment takes place in other variables apart from bank loan growth. In addition, the long-run estimates can be interpreted as approximate cumulative effects over the next year. $* * * * 0.01, * * p<0.05, * p<0.1$

The estimates in the first row indicate that changes in nominal interest rates largely affect bank loan growth through the effect of realized interest rate risk exposure on economic capital. The corresponding long-run effect is statistically highly significant, whereas the immediate effect is not significant. This result is consistent with the intuition that anticipated losses in economic capital alter bank lending in future periods. To obtain a first interpretation of the magnitude of this effect, consider how a $1 \mathrm{pp}$ upward shift in nominal interest rates affects two hypothetical banks, $A$ and $B$, that differ only in interest rate risk exposure. Bank $A$ will experience an economic loss equivalent to $5 \%$ of its eligible capital if interest rates rise by 1 pp over all maturities, i.e., $\rho_{A, t} / E l i g C_{t-1}=-5 \%$. Bank $B$, on the other hand, is relatively more exposed and its economic loss will amount to $6 \%$ of its eligible capital, i.e., $\rho_{B, t} / E l i g C_{t-1}=-6 \%$. The estimated coefficients indicate that bank $B$ 's quarter-on-quarter loan growth would be lower by $-0.05-(-0.06) \times 1 \mathrm{pp} \times 1.94=1.94 \mathrm{bp}$ than $A$ 's immediately after the shock, and its cumulative loan growth after one year would be approximately $-0.05-(-0.06) \times 1 \mathrm{pp} \times 8.96=$ $8.96 \mathrm{bp}$ lower. Therefore, we find evidence for a strong BCC that is driven by realized interest rate risk exposure.

In contrast, changes in nominal interest rates have no significant effect on bank loan growth via excess liquidity or excess capital levels. Thus, we find neither evidence for a BLC acting through excess liquidity and the bank's "lemon premium" nor for higher anticipated default rates having an effect on bank loan growth. An explanation for the absence of a BLC in our data 
may be that over the sample period from 2001Q2 to 2013Q3, the vast majority of Swiss banks did not experience any strains on liquidity and the real economy was stable, so defaults among borrowers were relatively rare. Moreover, many cantonal banks enjoy implicit or explicit state guarantees that may render the "lemon premium" that they must pay for uninsured short-term funding small and unresponsive to their level of excess capital.

Finally, the direct impact of both short- and long-term interest rates on bank loan growth capture the remaining supply and demand effects, which we cannot further disentangle. The coefficients on short-term interest rates are large in absolute value and significant, whereas those on long-term interest rates remain both smaller in absolute value and statistically insignificant.

\subsection{Ceteris paribus effect of interest rate risk exposure}

We now explore in more detail the extent to which interest rate risk exposure affects the sensitivity of bank loan growth to movements in nominal interest rates. In particular, we analyze the ceteris paribus effect of interest rate risk exposure for a permanent $1 \mathrm{pp}$ increase in nominal interest rates over all maturities on the average bank in the sample.

The solid black line in Figure 2 represents the predicted change in the average bank's cumulative loan growth in response to a permanent $1 \mathrm{pp}$ increase in nominal interest rates occurring at time $t .{ }^{9}$ To predict the immediate effect - i.e., in period $t$ - we take the model's most contemporaneous coefficients and evaluate equation (3)'s derivative with respect to $\Delta i_{t}=\Delta i_{t}^{3 M}=$ $\Delta i_{t}^{10 Y}=1 \mathrm{pp}$ at the average bank's characteristics in time $t .{ }^{10}$ To predict how the effect evolves over the subsequent quarters - i.e., over periods $t+s, s=1 \ldots 4$ - we must consider the dynamics of the model, as described in appendix A.4.

The dashed lines in Figure 2 illustrate the ceteris paribus effect of interest rate risk exposure. They correspond to the predicted response of the average bank's cumulative loan growth to the permanent $1 \mathrm{pp}$ increase in nominal interest rates, assuming that its interest rate risk exposure equals the 1st and 9th decile, respectively, keeping all other characteristics constant. Consequently, the dashed lines represent the average bank's predicted reaction to the interest rate increase, if it had an interest rate risk exposure corresponding to 1st and 9th decile, respectively.

Comparing the solid and dashed lines in Figure 2 reveals that interest rate risk exposure has a substantial impact on the sensitivity of bank loan growth. Immediately after the 1 pp shock in nominal interest rates, the predicted decline in quarterly loan growth amounts to $46 \mathrm{bp}$ for the average bank in the sample. However, if, ceteris paribus, this bank had an interest risk exposure equal to the 1 st or 9 th decile, respectively, the predicted decline would instead amount to $37 \mathrm{bp}$ and $55 \mathrm{bp}$. In the long run, the impact of interest rate risk exposure increases, as illustrated by the widening spread between the dashed lines. A year after the shock - i.e., in period $t+4-$ the

9 Time $t$ refers to the last available period in our sample, i.e., 2013Q3.

${ }^{10}$ Calculation details can be found in appendix A.4. 
Figure 2: Cumulative effect of a permanent 1 percentage point upward shock in nominal interest rates on bank loan growth

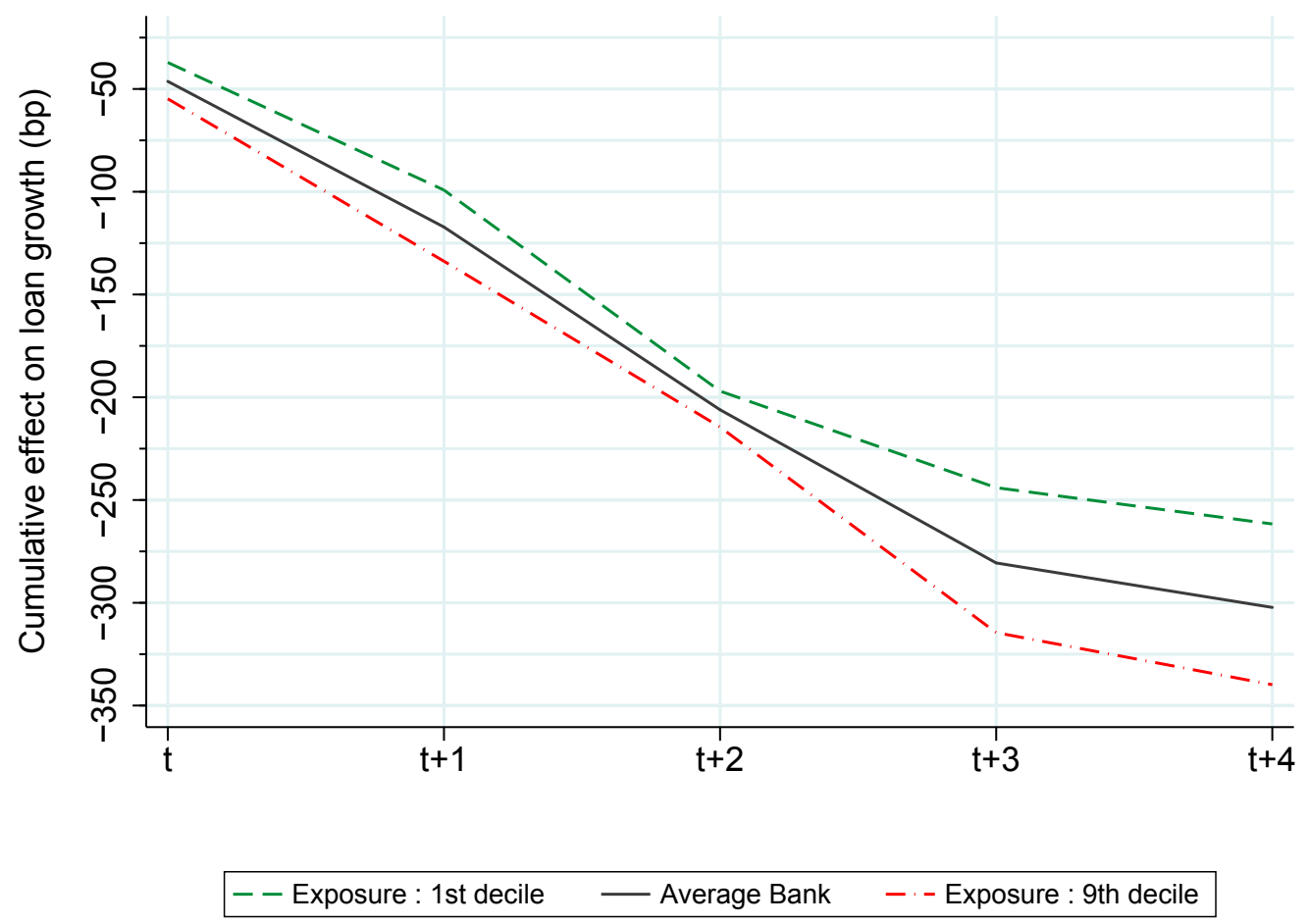

cumulative predicted decline in the average bank's loan growth is $300 \mathrm{bp} .{ }^{11}$ A decomposition of this predicted decline illustrates that approximately $12.5 \%$ of the decline is attributable to realized interest rate risk. In comparison, for an interest rate risk exposure equal to the 1st or 9th decile, respectively, the total predicted decline would, ceteris paribus, amount to either 260 bp or $340 \mathrm{bp}$. In these cases, interest rate risk exposure's contribution to the predicted declines amounts to $-1.1 \%$ and $22 \%$, respectively. The realized interest rate risk's positive contribution to cumulative loan growth in the 1st decile is attributable to the fact that the exposure is indeed positive - i.e., an interest rate increase would indeed be beneficial for the $10 \%$ least exposed banks.

The substantial impact and vast heterogeneity of interest risk exposure indicate that the decline in loan growth following an interest rate shock not only would be large in magnitude but also would vary greatly across banks. In particular, if nominal interest rates were to increase suddenly, we would expect the highly exposed banks in the sample to decrease their lending substantially more than the average bank.

\subsection{Robustness checks}

This subsection presents three main robustness checks. First, we explore alternative assumptions about the movement of the yield curve rates used to discount cash flows in our measure

${ }^{11}$ Remember that the total impact over time works under the ceteris paribus assumption of no adjustment in other variables besides bank loan growth. 
of interest rate risk exposure. Second, we check whether the results remain robust when we include the two big banks in the sample. Finally, we assess whether the unbalanced nature of the panel influences the results.

\subsubsection{Alternative definitions of interest rate risk}

Our baseline measure of interest rate risk works under the assumption of parallel movements in the yield curve rates used to discount cash flows. We use two alternative definitions of yield curve movement. In column (2) we employ a data-driven representative level movement in yield curve rates using a principal component analysis (PCA) of the yield curve. In column (3) we employ the actual changes in the yield curve to directly measure the movements in each maturity band, removing the requirement for any assumptions on the yield curve movements. ${ }^{12}$

Table 4: Robustness checks using alternative definitions of realized interest rate risk

\begin{tabular}{lccc}
\hline \hline Variables & Baseline & PCA & $\begin{array}{c}\text { One-Step } \\
(1)\end{array}$ \\
\hline Realized Interest Rate Risk & $8.96^{* * *}$ & $8.12^{* * * *}$ & $10.95^{* * *}$ \\
(fraction of eligible capital) & $(3.26)$ & $(2.98)$ & $(3.49)$ \\
Normalized Excess Liquidity $\times \Delta i^{3 M}$ & -0.06 & -0.06 & -0.09 \\
& $(0.14)$ & $(0.14)$ & $(0.15)$ \\
Normalized Excess Capital $\times \Delta i^{3 M}$ & -0.03 & -0.03 & 0.19 \\
& $(0.90)$ & $(0.90)$ & $(0.93$ \\
Normalized Size $\times \Delta i^{3 M}$ & -0.06 & -0.06 & -0.13 \\
& $(0.08)$ & $(0.08)$ & $(0.08)$ \\
$\Delta$ Short-term interest rate $\left(\Delta i^{3 M}\right)$ & $-2.54^{* * *}$ & $-2.53 * * *$ & $-2.47 * * *$ \\
& $(0.48)$ & $(0.48)$ & $(0.50)$ \\
$\Delta$ Long-term interest rate $\left(\Delta i^{10 Y}\right)$ & -0.18 & -0.18 & 0.24 \\
& $(0.32)$ & $(0.32)$ & $(0.31)$ \\
\hline \hline
\end{tabular}

Notes : Dependent variable is the first difference of log quarterly loan volume, i.e. approximately the quarter on quarter loan growth rate. Estimates using the Within Groups transformation. All standard errors, in parentheses, are cluster robust at a bank level. All estimates are long-run effects. The standard errors are calculated using the delta-method. $* * * p<0.01, * * p<0.05, * p<0.1$

Table 4 summarizes the results of the alternative yield curve movement definitions. Column (2) reports a point estimate that is slightly smaller than the baseline point estimate. Column (3)'s point estimate is larger than the point estimate in the baseline, but the $95 \%$ confidence intervals overlap. In summary, our results remain robust if we use the alternative definitions of realized interest rate risk.

${ }^{12}$ Essentially, equation (1) becomes $\rho_{i t}=\sum_{m=1}^{18} C F(m)_{i t} \cdot\left[D F(m)_{t+1}-D F(m)_{t}\right]$, thereby using actual changes in the yield curve at each maturity band. 


\subsubsection{Including the two big banks}

Table 5 summarizes the estimation results based on the sample that includes the two big banks. The point estimates remain practically unchanged in comparison to those found in Table 3.

Table 5: Robustness check including the two big banks

\begin{tabular}{lcc}
\hline \hline Variables & Immediate & Long-Run \\
\hline Realized Interest Rate Risk & 2.06 & $11.06^{* * * *}$ \\
(fraction of eligible capital) & $(2.05)$ & $(3.07)$ \\
Normalized Excess Liquidity $\times \Delta i^{3 M}$ & -0.08 & -0.04 \\
& $(0.11)$ & $(0.15)$ \\
Normalized Excess Capital $\times \Delta i^{3 M}$ & -0.17 & -0.21 \\
& $(0.88)$ & $(0.88)$ \\
Normalized Size $\times \Delta i^{3 M}$ & 0.07 & 0.10 \\
$\Delta$ Short-term interest rate $\left(\Delta i^{3 M}\right)$ & $(0.05)$ & $(0.08)$ \\
$\Delta$ Long-term interest rate $\left(\Delta i^{10 Y}\right)$ & $-0.43 * *$ & $-1.97 * * *$ \\
& $(0.17)$ & $(0.51)$ \\
\hline \hline
\end{tabular}

Notes : Dependent variable is the first difference of log quarterly loan volume, i.e. approximately the quarter on quarter loan growth rate. Estimates using the Within Groups transformation in Table A3. All standard errors, in parentheses, are cluster robust at a bank level. Immediate effect standard errors are simply regression estimates. Long-run effect standard errors are calculated using the delta-method. The long-run effects work under the assumption that no adjustment takes place in other variables apart from bank loan growth. In addition, the long-run estimates can be interpreted as approximate cumulative effects over the next year. ${ }^{* * *} p<0.01, * * p<0.05, * p<0.1$

It is noteworthy that the direct effect of short-term interest rates on bank loan growth diminishes slightly when we include the two big banks in the estimation sample. In addition, the point estimate on realized interest rate risk increases with respect to the estimation without big banks. However, the results do not significantly differ from baseline results without the two big banks.

\subsubsection{Assessing the influence of the unbalanced panel data}

Another concern is that the unbalanced nature of the panel data set influences the results. Although the sample period from 2001Q2 to 2013Q3 covers $T=50$ quarters, we only observe 62 banks over the whole period. Another 8 banks either left - primarily because of mergers and acquisitions - or newly entered the sample between 2001Q2 and 2013Q3. To check whether the unbalanced nature of the panel data set has an influence on the results, we re-estimated our model including only banks that we observe for at least 10, 15, and 20 periods. As shown in Table A5 in the appendix, the results remain robust. 


\section{Conclusion}

Our results are policy relevant in various ways. First, they indicate that the level of banks' exposure to interest rate risk must be considered when attempting to understand how changes in interest rates affect bank loan growth. Our results suggest that individual bank loan growth has likely become more sensitive to changes in interest rates than it was prior to the recent increase in interest rate risk exposure. Even though our estimates cannot be directly aggregated because they are based on individual data and do not consider eventual general equilibrium effects, they still indicate that a given upward shock in nominal interest rates would probably have a greater effect on bank lending today experience prior to the recent increase in interest rate risk exposure suggests. Furthermore, because the banks in our sample have become more heterogeneous in interest rate risk exposure, even a relatively small shock could cause substantial losses in economic capital at the most exposed institutions, leading them to significantly decrease their lending. In parallel, if interest rate risk is heterogeneous across regions, an interest rate shock may have redistributive effects. Finally, the finding that bank lending is mainly driven by capital instead of liquidity suggests that larger capital buffers would make bank lending more resilient against shocks in nominal interest rates, whereas larger liquidity buffers would only have a relatively small or even no effect. Similar conclusions are drawn in recent work published in BIS (2015).

However, a few limitations regarding our measure of interest rate risk should be mentioned here. The measure is exclusively based on the loss in economic capital attributable to banks' repricing mismatches. Thus, it ignores the fact that in the current environment of negative short-term interest rates, an upward shock in nominal interest rates would benefit the banks in two ways: (1) they would have to pay less negative interest rates on their sight deposit accounts at the central bank and (2) simultaneously, their liability margin would be restored. ${ }^{13}$ These two effects could at least partly offset the economic loss arising from repricing mismatches. However, our measure may underestimate the banks' true exposure to interest rate risk because their assumptions regarding positions with undefined repricing maturities may be too optimistic, especially if the shock is substantial and interest rates on deposits need to be adjusted faster than expected.

Finally, there is room for future research. One important open question is how changes in the maturity of bank lending affect the transmission of monetary policy. On one hand, our results suggest that increased interest rate risk exposure renders bank lending to the real sector more sensitive to changes in nominal interest rates. On the other hand, increased repricing maturity of loans originating from increased interest rate risk exposure temporarily shields ex-

13 The liability margin is the difference between the alternative funding costs for the corresponding maturity on the capital market and the interest paid on the actual liability. It recently became negative for most banks. After the introduction of negative interests on sight deposits at the SNB, some capital and money market interest rates also became negative, whereas the interest rates on customer sight and savings deposits remained close to zero but positive (SNB, 2015). 
isting borrowers from changes in interest rates. Furthermore, as loan-level data become more readily available, it should become possible to account for borrower characteristics that fall under the balance sheet channel of monetary policy transmission. In summary, our results should prove helpful for better understanding the transmission of monetary policy via the banking system. As such, our results constitute only a first step toward the integration of banking sector characteristics into policy making, an important question that is beyond the scope of this paper. 


\section{References}

Alvarez, J. and Arellano, M. (2003), 'The time series and cross-section asymptotics of dynamic panel data estimators', Econometrica 71(4), 1121-1159.

Arellano, M. and Bond, S. (1991), 'Some tests of specification for panel data: Monte carlo evidence and an application to employment equations', The Review of Economic Studies 58(2), 277-297.

Arellano, M. and Bover, O. (1995), 'Another look at the instrumental variable estimation of error-components models', Journal of Econometrics 68(1), 29-51.

Arellano, M. and Honoré, B. (2001), 'Panel data models: some recent developments', Handbook of Econometrics 5, 3229-3296.

Bernanke, B. S. and Blinder, A. S. (1988), 'Credit, money, and aggregate demand', The American Economic Review pp. 435-439.

Bernanke, B. S. and Gertler, M. (1995), 'Inside the black box: The credit channel of monetary policy', The Journal of Economic Perspectives 9(4), 27-48.

Bichsel, R. and Perrez, J. (2005), 'In quest of the bank lending channel: evidence for switzerland using individual bank data', Swiss Journal of Economics and Statistics 141(2), 165-190.

BIS (2015), 'Interest rate risk in the banking book'.

Blundell, R. and Bond, S. (1998), 'Initial conditions and moment restrictions in dynamic panel data models', Journal of Econometrics 87(1), 115-143.

Bond, S. R. (2002), 'Dynamic panel data models: a guide to micro data methods and practice', Portuguese Economic Journal 1(2), 141-162.

Bruno, G. S. (2005), 'Approximating the bias of the lsdv estimator for dynamic unbalanced panel data models', Economics Letters 87(3), 361-366.

Cornett, M. M. and Tehranian, H. (1994), 'An examination of voluntary versus involuntary security issuances by commercial banks: The impact of capital regulations on common stock returns', Journal of Financial Economics 35(1), 99-122.

Gambacorta, L. and Mistrulli, P. E. (2004), 'Does bank capital affect lending behavior?', Journal of Financial Intermediation 13(4), 436-457.

Hanson, S. G. and Stein, J. C. (2015), 'Monetary policy and long-term real rates', Journal of Financial Economics 115(3), 429-448. 
Jiménez, G., Ongena, S., Peydró, J.-L. and Saurina, J. (2012), 'Credit supply and monetary policy: Identifying the bank balance-sheet channel with loan applications', The American Economic Review 102(5), 2301-2326.

Judson, R. A. and Owen, A. L. (1999), 'Estimating dynamic panel data models: a guide for macroeconomists', Economics Letters 65(1), 9-15.

Kashyap, A. K. and Stein, J. C. (1995), The impact of monetary policy on bank balance sheets, in 'Carnegie-Rochester Conference Series on Public Policy', Vol. 42, Elsevier, pp. 151-195.

Kashyap, A. K. and Stein, J. C. (2000), 'What do a million observations on banks say about the transmission of monetary policy?', American Economic Review pp. 407-428.

Kishan, R. P. and Opiela, T. P. (2000), 'Bank size, bank capital, and the bank lending channel', Journal of Money, Credit and Banking pp. 121-141.

Kishan, R. P. and Opiela, T. P. (2006), 'Bank capital and loan asymmetry in the transmission of monetary policy', Journal of Banking \& Finance 30(1), 259-285.

Kiviet, J. F. (1995), 'On bias, inconsistency, and efficiency of various estimators in dynamic panel data models', Journal of Econometrics 68(1), 53-78.

Kwan, S. and Eisenbeis, R. A. (1997), 'Bank risk, capitalization, and operating efficiency', Journal of Financial Services Research 12(2-3), 117-131.

Landier, A., Sraer, D. A. and Thesmar, D. (2015), 'Banks' exposure to interest rate risk and the transmission of monetary policy', Available at SSRN 2220360 .

Myers, S. C. (2001), 'Capital structure', Journal of Economic Perspectives pp. 81-102.

Myers, S. C. and Majluf, N. S. (1984), 'Corporate financing and investment decisions when firms have information that investors do not have', Journal of Financial Economics 13(2), 187-221.

Nickell, S. (1981), 'Biases in dynamic models with fixed effects', Econometrica: Journal of the Econometric Society pp. 1417-1426.

Roodman, D. (2009), 'How to do xtabond2: An introduction to difference and system gmm in stata', Stata Journal 9(1), 86.

SNB (2014), 'Financial stability report'.

SNB (2015), 'Financial stability report'.

Turner, P. (2013), Benign neglect of the long-term interest rate, Technical report, Bank for International Settlements. 
Van den Heuvel, S. (2007), The bank capital channel of monetary policy, in '2007 Meeting Papers', number 512, Society for Economic Dynamics.

Van den Heuvel, S. J. (2002), 'Does bank capital matter for monetary transmission?', Economic Policy Review 8(1), 259-265. 


\section{A Appendices}

\section{A.1 Data preparation}

\section{A.1.1 Outliers}

We address outliers in the loan growth series using the hadimvo Stata program with a threshold at 0.01 . Essentially, it removes the observations in the tails of the distribution, dropping 30 observations out of 3,295 observations. We retain the remaining outlier-free series of bank loan growth for the analysis.

\section{A.1.2 Normalizations}

The normalizations on the outlier-free data for excess capital, liquidity and size work as follows. Formally, excess capital and liquidity are given by

$$
X_{i t}=\frac{E_{i t}^{X}}{R_{i t}^{X}}-\left(\sum_{t} \frac{\sum_{i} E_{i t}^{X} / R_{i t}^{X}}{N_{t}}\right) / T,
$$

where $X$ is either $C$ for capital or $B$ for liquidity and $E^{X}$ and $R^{X}$ are excess and required quantities, respectively. Therefore, we subtract the sample average from excess capital and liquidity, which yields a variable centered around zero. This should be interpreted as whether the bank had more or less of the corresponding excess quantity in a given quarter than the average over all banks and over the entire sample period.

Size is normalized with respect to the sample average in each period, which removes the trending nature of the size variable. We adopt the following measure:

$$
S_{i t}=S i z e_{i t}-\left(\frac{\sum_{i} S i z e_{i t}}{N_{t}}\right)
$$

\section{A.1.3 Mergers and acquisitions}

We need to account for the discrete jumps that are created by 25 mergers and acquisitions in our data set during the sample period. The underlying method works as follows: (i) identify the banks that perform a merger and acquisition as well as the banks that are subject to a merger and acquisition in a given quarter; (ii) under the assumption that the acquired/absorbed banks cease to exist in the quarter of the transaction, remove all observations of those banks from the transaction onward (and including the quarter of the transaction), but this only occurs in one case; and (iii) concerning the acquiring bank, allocate it a new id from the quarter of the transaction onward. This procedure accommodates the Gambacorta and Mistrulli (2004) approach, generating a so-called merger-id that we use to account for bank-level fixed effects in our estimations.

In terms of entries and exits of banks during the sample, we start with 77 banks in 2001Q2 
and end with 68 banks in 2013Q3. The majority of the fluctuation is attributable to a consolidation of the banking system via mergers and acquisitions that occurred over the sample period. There is no systematic exit or entry of banks.

\section{A.2 Estimation discussion}

The estimation of dynamic panel data models may suffer from endogeneity bias because of the inclusion of lagged dependent variables among the regressors. Consider the following stylized version of our model:

$$
y_{i t}=\alpha y_{i t-1}+\beta x_{i t}+\left(\mu_{i}+\epsilon_{i t}\right), \quad|\alpha|<1,
$$

for $i=1, \ldots, N$ and $t=2, \ldots, T$.

A pooled Ordinary Least Squares (OLS) estimation of (4) generates an upward biased estimate on the $\alpha$ coefficient. This upward bias results from the positive correlation between the lagged dependent variable, $y_{i t-1}$, and the individual fixed effect, $\mu_{i}$, in the composite error term.

Similarly, the within groups fixed effects estimator (WG) mechanically introduces a downward bias on the $\alpha$ coefficient. This downward bias results from the negative correlation of order $1 /(T-1)$ between the transformed lagged dependent variable, $\tilde{y}_{i t-1}$, and the transformed error term, $\tilde{\epsilon}_{i t}$. The literature refers to this bias as the "Nickell Bias" (Nickell, 1981).

The standard way to address this endogeneity problem is to implement the Generalized Method of Moments (GMM) approach developed by Arellano and Bond (1991) and extended by Arellano and Bover (1995) and Blundell and Bond (1998). Essentially, this GMM approach alleviates the endogeneity bias by eliminating the fixed effects using a differenced equation and instrumenting the resulting equation with internal lagged level versions of the equation's variables. Ultimately, GMM estimates of $\alpha$ should fall between the OLS and WG estimates.

Note, however, that the "Nickell Bias" of the WG estimator becomes negligible when the time dimension of the panel is sufficiently large. ${ }^{14}$ The correlation is non-negligible for panels with a small $T$, but becomes negligible as $T$ increases. Excluding the additional explanatory variables, the âĂIJNickell BiasâĂİ is given by (Nickell, 1981):

$$
\operatorname{plim}_{N \rightarrow \infty}(\hat{\alpha}-\alpha) \simeq-\frac{(1+\alpha)}{T-1}
$$

Therefore, a larger time dimension reduces the extent of the bias. A more general result that includes explanatory variables follows naturally.

Simulation studies reveal that the "Nickell Bias" becomes negligible for $T>30$ (Bruno, 2005; Judson and Owen, 1999; Kiviet, 1995). In addition, any bias on the estimates of explanatory variable coefficients depends on the relation of the explanatory variables with the lagged

14 Alvarez and Arellano (2003) show that under certain conditions, the WG estimator has the distribution $\sqrt{N T}\left[\hat{\alpha}-\left(\alpha-\frac{1}{T}(1+\alpha)\right)\right] \stackrel{d}{\rightarrow} N\left(0,1-\alpha^{2}\right)$. Large time dimensions reduce the bias $\frac{1}{T}(1+\alpha)$. 
dependent variable but remains slight in comparison.

Given the results of these simulation studies and the large time dimension of our panel i.e., $T=50$, we can safely rely on the WG estimator as the "Nickell Bias" becomes negligible. Using the WG estimator instead of the GMM estimator has two advantages. First, the WG estimator is generally more efficient in practice (Arellano and Honoré, 2001; Kiviet, 1995; Alvarez and Arellano, 2003). Second, we can avoid making somewhat arbitrary choices about the instrument's specific structure and the number of lags that are necessary when implementing the GMM estimator.

Table A3 in the appendix shows the coefficients of our model estimated using OLS, WG, and different versions of GMM. This table confirms that the WG and GMM estimators yield similar results and that the WG estimator tends to be more efficient. Consequently, all of the results in the following section are based on the WG estimator.

\section{A.3 Estimator comparisons}

Table A3 shows the OLS, WG, and GMM estimates of the model presented in equation (3). Its primary objective is to study whether the estimates change across the different estimators as expected, given the discussion in section A.2.

The first two columns depict the OLS and WG estimates. The subsequent columns (3 to 6) show the estimates of different implementations of the GMM estimator that are typically found in settings with dynamic panel models. The optimal implementation of the one-step System GMM estimator depends on various criteria, namely: (i) the equation structure; (ii) the choice of instrument structure ${ }^{15}$; (iii) the number of instruments ${ }^{16}$; (iv) the lack of second order autocorrelation in the errors; and (v) over-identification tests. Columns 3 and 4 exploit the GMM-style instruments that create an instrument matrix, in which one column is generated for each time period and lag available. In contrast, columns 5 and 6 use so-called "stacked" instruments, which are a reduced column format of the GMM-style instrument structure.

Points (ii) and (iii) are important in determining how the GMM estimator addresses the "Nickell Bias." More specifically, the GMM-style instrument structure takes on the following form:

$$
\left(\begin{array}{ccccccc}
0 & 0 & 0 & 0 & 0 & 0 & \ldots \\
y_{i 1} & 0 & 0 & 0 & 0 & 0 & \ldots \\
0 & y_{i 2} & y_{i 1} & 0 & 0 & 0 & \ldots \\
0 & 0 & 0 & y_{i 3} & y_{i 2} & y_{i 1} & \ldots \\
\vdots & \vdots & \vdots & \vdots & \vdots & \vdots & \ddots
\end{array}\right) .
$$

Each column is generated for a given row so that it contains the information of each lag that is available in that period. In contrast, the stacked instrument structure greatly reduces the number

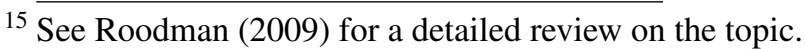

${ }^{16}$ See Blundell and Bond (1998); Bond (2002) for examples.
} 
of columns that are generated and can be represented as follows:

$$
\left(\begin{array}{cccc}
0 & 0 & 0 & \ldots \\
y_{i 1} & 0 & 0 & \ldots \\
y_{i 2} & y_{i 1} & 0 & \ldots \\
y_{i 3} & y_{i 2} & y_{i 1} & \ldots \\
\vdots & \vdots & \vdots & \ddots
\end{array}\right) .
$$

Therefore, choosing between GMM-style and stacked instruments can have a substantial influence on the number of instruments used in the estimation process.

Point (iv) investigates the autocorrelation in the idiosyncratic error term, $\epsilon_{i t}$. First-order correlation would mean that lagged instruments starting at $t-2$ would no longer be valid, requiring the instruments to start at lag $t-3$. First-order autocorrelation in the differenced errors (AR(1) p-value) is essentially uninformative because of the share of $\epsilon_{i t-1}$ in both $\Delta \epsilon_{i t}$ and $\Delta \epsilon_{i t-1}$, but should recover the mechanically negative correlation because of the differencing of the levels equation in the GMM estimation process. Therefore, no first-order autocorrelation in levels is equivalent to no second-order autocorrelation in differences, i.e., between $\epsilon_{i t-1}$ in $\Delta \epsilon_{i t}$ and $\epsilon_{i t-2}$ in $\Delta \epsilon_{i t-2}$. In all of the columns, the results suggest that there is no first-order correlation $(\operatorname{AR}(2)$ p-value) in the level idiosyncratic errors. That said, we still account for the potential heteroscedasticity and autocorrelation in the errors at each bank by clustering the errors at a bank level. 
Table A3: Estimated Coefficients

\begin{tabular}{|c|c|c|c|c|c|c|}
\hline Variables & OLS & (2) & $\begin{array}{c}(3) \\
\text { GMM SYS t-2: } \\
\text { GMM-Style } \\
\text { Instruments }\end{array}$ & $\begin{array}{c}\text { (4) } \\
\text { GMM SYS t-3: } \\
\text { GMM-Style } \\
\text { Instruments }\end{array}$ & $\begin{array}{c}(5) \\
\text { GMM SYS t-2: } \\
\text { Stacked } \\
\text { Instruments }\end{array}$ & $\begin{array}{c}(6) \\
\text { GMM SYS t-3: } \\
\text { Stacked } \\
\text { Instruments }\end{array}$ \\
\hline$\Delta \ln L_{i t-1}$ & $\begin{array}{c}0.452 * * * \\
(0.045)\end{array}$ & $\begin{array}{c}0.320 * * * \\
(0.042)\end{array}$ & $\begin{array}{c}0.428 * * * \\
(0.042)\end{array}$ & $\begin{array}{c}0.488 * * * \\
(0.048)\end{array}$ & $\begin{array}{c}0.313 * * * \\
(0.057)\end{array}$ & $\begin{array}{c}0.387 * * * \\
(0.107)\end{array}$ \\
\hline$\left(\frac{\rho_{i t-1} \times \Delta i_{t}}{E l i g C_{i t-1}}\right)_{i t}$ & $\begin{array}{c}1.674 \\
(2.181)\end{array}$ & $\begin{array}{c}1.936 \\
(2.107)\end{array}$ & $\begin{array}{c}1.990 \\
(2.160)\end{array}$ & $\begin{array}{c}2.580 \\
(2.264)\end{array}$ & $\begin{array}{l}-0.628 \\
(4.955)\end{array}$ & $\begin{array}{c}-1.938 \\
(11.993)\end{array}$ \\
\hline$\left(\frac{\rho_{i t-1} \times \Delta i_{t}}{E l i g C_{i t-1}}\right)_{i t-1}$ & $\begin{array}{c}0.690 \\
(2.809)\end{array}$ & $\begin{array}{c}1.235 \\
(2.694)\end{array}$ & $\begin{array}{c}0.685 \\
(2.733)\end{array}$ & $\begin{array}{l}-0.132 \\
(2.971)\end{array}$ & $\begin{array}{l}-3.322 \\
(7.419)\end{array}$ & $\begin{array}{c}0.781 \\
(9.456)\end{array}$ \\
\hline$\left(\frac{\rho_{i t-1} \times \Delta i_{t}}{E l i g C_{i t-1}}\right)_{i t-2}$ & $\begin{array}{l}-1.996 \\
(2.240)\end{array}$ & $\begin{array}{l}-2.472 \\
(2.112)\end{array}$ & $\begin{array}{l}-1.714 \\
(2.182)\end{array}$ & $\begin{array}{l}-1.747 \\
(2.246)\end{array}$ & $\begin{array}{l}-1.242 \\
(4.942)\end{array}$ & $\begin{array}{l}-0.498 \\
(5.820)\end{array}$ \\
\hline$\left(\frac{\rho_{i t-1} \times \Delta i_{t}}{E l i g C_{i t-1}}\right)_{i t-3}$ & $\begin{array}{c}6.605 * * * \\
(1.686)\end{array}$ & $\begin{array}{c}6.407 * * * \\
(1.656)\end{array}$ & $\begin{array}{c}6.668 * * * \\
(1.639)\end{array}$ & $\begin{array}{c}6.000 * * * \\
(1.700)\end{array}$ & $\begin{array}{c}10.989 * * * \\
(3.037)\end{array}$ & $\begin{array}{l}9.068 * * \\
(4.093)\end{array}$ \\
\hline$\left(\frac{\rho_{i t-1} \times \Delta i_{t}}{E l i g C_{i t-1}}\right)_{i t-4}$ & $\begin{array}{l}-1.216 \\
(1.525)\end{array}$ & $\begin{array}{l}-1.016 \\
(1.613)\end{array}$ & $\begin{array}{l}-0.879 \\
(1.522)\end{array}$ & $\begin{array}{l}-1.425 \\
(1.550)\end{array}$ & $\begin{array}{c}3.665 \\
(3.875)\end{array}$ & $\begin{array}{c}1.212 \\
(3.672)\end{array}$ \\
\hline$B_{i t-1} \cdot \Delta i_{t}^{3 M}$ & $\begin{array}{l}-0.035 \\
(0.105)\end{array}$ & $\begin{array}{l}-0.073 \\
(0.108)\end{array}$ & $\begin{array}{l}-0.044 \\
(0.103)\end{array}$ & $\begin{array}{c}0.033 \\
(0.119)\end{array}$ & $\begin{array}{c}0.181 \\
(0.924)\end{array}$ & $\begin{array}{l}-0.146 \\
(0.891)\end{array}$ \\
\hline$B_{i t-1} \cdot \Delta i_{t-1}^{3 M}$ & $\begin{array}{c}0.070 \\
(0.177)\end{array}$ & $\begin{array}{c}0.097 \\
(0.174)\end{array}$ & $\begin{array}{c}0.072 \\
(0.175)\end{array}$ & $\begin{array}{c}0.055 \\
(0.198)\end{array}$ & $\begin{array}{l}-1.057 \\
(0.943)\end{array}$ & $\begin{array}{l}-0.049 \\
(0.855)\end{array}$ \\
\hline$B_{i t-1} \cdot \Delta i_{t-2}^{3 M}$ & $\begin{array}{c}0.058 \\
(0.189)\end{array}$ & $\begin{array}{c}0.065 \\
(0.181)\end{array}$ & $\begin{array}{c}0.064 \\
(0.186)\end{array}$ & $\begin{array}{c}0.058 \\
(0.219)\end{array}$ & $\begin{array}{l}-0.383 \\
(0.964)\end{array}$ & $\begin{array}{l}-0.801 \\
(0.947)\end{array}$ \\
\hline$B_{i t-1} \cdot \Delta i_{t-3}^{3 M}$ & $\begin{array}{l}-0.045 \\
(0.134)\end{array}$ & $\begin{array}{l}-0.033 \\
(0.122)\end{array}$ & $\begin{array}{l}-0.040 \\
(0.131)\end{array}$ & $\begin{array}{l}-0.030 \\
(0.155)\end{array}$ & $\begin{array}{l}-0.134 \\
(0.613)\end{array}$ & $\begin{array}{l}-0.018 \\
(0.590)\end{array}$ \\
\hline$B_{i t-1} \cdot \Delta i_{t-4}^{3 M}$ & $\begin{array}{l}-0.099 \\
(0.088)\end{array}$ & $\begin{array}{l}-0.096 \\
(0.079)\end{array}$ & $\begin{array}{l}-0.100 \\
(0.085)\end{array}$ & $\begin{array}{l}-0.134 \\
(0.106)\end{array}$ & $\begin{array}{l}-0.409 \\
(0.694)\end{array}$ & $\begin{array}{l}-0.781 \\
(0.673)\end{array}$ \\
\hline$C_{i t-1} \cdot \Delta i_{t}^{3 M}$ & $\begin{array}{c}0.054 \\
(0.255)\end{array}$ & $\begin{array}{l}-0.160 \\
(0.276)\end{array}$ & $\begin{array}{c}0.057 \\
(0.253)\end{array}$ & $\begin{array}{c}0.066 \\
(0.249)\end{array}$ & $\begin{array}{c}2.428 \\
(1.750)\end{array}$ & $\begin{array}{c}2.801 \\
(1.874)\end{array}$ \\
\hline$C_{i t-1} \cdot \Delta i_{t-1}^{3 M}$ & $\begin{array}{c}0.418 \\
(0.364)\end{array}$ & $\begin{array}{c}0.303 \\
(0.354)\end{array}$ & $\begin{array}{c}0.400 \\
(0.358)\end{array}$ & $\begin{array}{c}0.457 \\
(0.368)\end{array}$ & $\begin{array}{l}-0.239 \\
(1.435)\end{array}$ & $\begin{array}{l}-1.147 \\
(1.612)\end{array}$ \\
\hline$C_{i t-1} \cdot \Delta i_{t-2}^{3 M}$ & $\begin{array}{c}0.242 \\
(0.377)\end{array}$ & $\begin{array}{c}0.150 \\
(0.377)\end{array}$ & $\begin{array}{c}0.249 \\
(0.362)\end{array}$ & $\begin{array}{c}0.259 \\
(0.371)\end{array}$ & $\begin{array}{l}-2.177 \\
(1.999)\end{array}$ & $\begin{array}{l}-0.922 \\
(1.838)\end{array}$ \\
\hline$C_{i t-1} \cdot \Delta i_{t-3}^{3 M}$ & $\begin{array}{c}0.174 \\
(0.218)\end{array}$ & $\begin{array}{c}0.181 \\
(0.210)\end{array}$ & $\begin{array}{c}0.160 \\
(0.217)\end{array}$ & $\begin{array}{c}0.187 \\
(0.231)\end{array}$ & $\begin{array}{l}-0.777 \\
(1.244)\end{array}$ & $\begin{array}{l}-1.566 \\
(1.239)\end{array}$ \\
\hline$C_{i t-1} \cdot \Delta i_{t-4}^{3 M}$ & $\begin{array}{l}-0.551 * \\
(0.298)\end{array}$ & $\begin{array}{l}-0.491 \\
(0.297)\end{array}$ & $\begin{array}{l}-0.551 * \\
(0.303)\end{array}$ & $\begin{array}{l}-0.536^{*} \\
(0.301)\end{array}$ & $\begin{array}{c}0.679 \\
(1.450)\end{array}$ & $\begin{array}{c}0.874 \\
(1.771)\end{array}$ \\
\hline Continued & & & & & & \\
\hline
\end{tabular}


Table A3 cont'd: Estimated Coefficients

\begin{tabular}{|c|c|c|c|c|c|c|}
\hline Variables & $\begin{array}{c}\text { (1) } \\
\text { OLS }\end{array}$ & (2) & $\begin{array}{c}(3) \\
\text { GMM SYS t-2: } \\
\text { GMM-Style } \\
\text { Instruments }\end{array}$ & $\begin{array}{c}(4) \\
\text { GMM SYS t-3: } \\
\text { GMM-Style } \\
\text { Instruments }\end{array}$ & $\begin{array}{c}(5) \\
\text { GMM SYS t-2: } \\
\text { Stacked } \\
\text { Instruments }\end{array}$ & $\begin{array}{c}(6) \\
\text { GMM SYS t-3: } \\
\text { Stacked } \\
\text { Instruments }\end{array}$ \\
\hline$\Delta i_{t}^{3 M}$ & $\begin{array}{c}-0.376^{* *} \\
(0.165)\end{array}$ & $\begin{array}{c}-0.461 * * * \\
(0.164)\end{array}$ & $\begin{array}{c}-0.357 * * \\
(0.161)\end{array}$ & $\begin{array}{l}-0.311 * \\
(0.162)\end{array}$ & $\begin{array}{c}-1.296 * * * \\
(0.432)\end{array}$ & $\begin{array}{c}-1.337 * * \\
(0.597)\end{array}$ \\
\hline$\Delta i_{t-1}^{3 M}$ & $\begin{array}{c}-0.300 * * \\
(0.149)\end{array}$ & $\begin{array}{c}-0.332 * * \\
(0.145)\end{array}$ & $\begin{array}{c}-0.301 * * \\
(0.148)\end{array}$ & $\begin{array}{c}-0.294 * \\
(0.157)\end{array}$ & $\begin{array}{l}-0.546 \\
(0.408)\end{array}$ & $\begin{array}{l}-0.342 \\
(0.455)\end{array}$ \\
\hline$\Delta i_{t-2}^{3 M}$ & $\begin{array}{c}-0.505 * * * \\
(0.173)\end{array}$ & $\begin{array}{c}-0.703 * * * \\
(0.181)\end{array}$ & $\begin{array}{c}-0.490 * * * \\
(0.172)\end{array}$ & $\begin{array}{c}-0.465 * * * \\
(0.174)\end{array}$ & $\begin{array}{l}-0.223 \\
(0.406)\end{array}$ & $\begin{array}{l}-0.290 \\
(0.381)\end{array}$ \\
\hline$\Delta i_{t-3}^{3 M}$ & $\begin{array}{l}-0.051 \\
(0.123)\end{array}$ & $\begin{array}{l}-0.201 \\
(0.128)\end{array}$ & $\begin{array}{l}-0.058 \\
(0.121)\end{array}$ & $\begin{array}{l}-0.042 \\
(0.124)\end{array}$ & $\begin{array}{l}-0.027 \\
(0.280)\end{array}$ & $\begin{array}{c}0.050 \\
(0.239)\end{array}$ \\
\hline$\Delta i_{t-4}^{3 M}$ & $\begin{array}{c}0.043 \\
(0.133)\end{array}$ & $\begin{array}{l}-0.032 \\
(0.140)\end{array}$ & $\begin{array}{c}0.053 \\
(0.130)\end{array}$ & $\begin{array}{c}0.060 \\
(0.132)\end{array}$ & $\begin{array}{l}-0.082 \\
(0.281)\end{array}$ & $\begin{array}{l}-0.178 \\
(0.282)\end{array}$ \\
\hline$\Delta i_{t}^{10 Y}$ & $\begin{array}{c}0.094 \\
(0.110)\end{array}$ & $\begin{array}{c}0.076 \\
(0.106)\end{array}$ & $\begin{array}{c}0.090 \\
(0.106)\end{array}$ & $\begin{array}{c}0.096 \\
(0.111)\end{array}$ & $\begin{array}{c}0.043 \\
(0.133)\end{array}$ & $\begin{array}{c}0.062 \\
(0.149)\end{array}$ \\
\hline$\Delta i_{t-1}^{10 Y}$ & $\begin{array}{l}-0.132 \\
(0.094)\end{array}$ & $\begin{array}{l}-0.155^{*} \\
(0.091)\end{array}$ & $\begin{array}{l}-0.126 \\
(0.093)\end{array}$ & $\begin{array}{l}-0.145 \\
(0.094)\end{array}$ & $\begin{array}{l}-0.069 \\
(0.127)\end{array}$ & $\begin{array}{l}-0.060 \\
(0.141)\end{array}$ \\
\hline$\Delta i_{t-2}^{10 Y}$ & $\begin{array}{l}-0.061 \\
(0.124)\end{array}$ & $\begin{array}{l}-0.061 \\
(0.117)\end{array}$ & $\begin{array}{l}-0.065 \\
(0.120)\end{array}$ & $\begin{array}{l}-0.044 \\
(0.123)\end{array}$ & $\begin{array}{c}-0.287 * \\
(0.157)\end{array}$ & $\begin{array}{l}-0.241 \\
(0.155)\end{array}$ \\
\hline$\Delta i_{t-3}^{10 Y}$ & $\begin{array}{c}0.073 \\
(0.129)\end{array}$ & $\begin{array}{c}0.046 \\
(0.120)\end{array}$ & $\begin{array}{c}0.081 \\
(0.124)\end{array}$ & $\begin{array}{c}0.063 \\
(0.129)\end{array}$ & $\begin{array}{l}-0.050 \\
(0.161)\end{array}$ & $\begin{array}{l}-0.043 \\
(0.172)\end{array}$ \\
\hline$\Delta i_{t-4}^{10 Y}$ & $\begin{array}{l}-0.051 \\
(0.116)\end{array}$ & $\begin{array}{l}-0.029 \\
(0.113)\end{array}$ & $\begin{array}{l}-0.050 \\
(0.113)\end{array}$ & $\begin{array}{l}-0.058 \\
(0.117)\end{array}$ & $\begin{array}{l}-0.040 \\
(0.151)\end{array}$ & $\begin{array}{l}-0.065 \\
(0.163)\end{array}$ \\
\hline$C_{i t-1}$ & $\begin{array}{c}0.216 \\
(0.190)\end{array}$ & $\begin{array}{c}0.016 \\
(0.244)\end{array}$ & $\begin{array}{c}0.250 \\
(0.217)\end{array}$ & $\begin{array}{c}0.293 \\
(0.203)\end{array}$ & $\begin{array}{l}-1.660 \\
(1.072)\end{array}$ & $\begin{array}{l}-1.568 \\
(1.155)\end{array}$ \\
\hline$B_{i t-1}$ & $\begin{array}{l}-0.007 \\
(0.035)\end{array}$ & $\begin{array}{c}0.029 \\
(0.044)\end{array}$ & $\begin{array}{l}-0.005 \\
(0.049)\end{array}$ & $\begin{array}{c}0.046 \\
(0.038)\end{array}$ & $\begin{array}{l}-0.279 * \\
(0.146)\end{array}$ & $\begin{array}{l}-0.279 \\
(0.187)\end{array}$ \\
\hline$S_{i t-1}$ & $\begin{array}{l}-0.025 \\
(0.016)\end{array}$ & $\begin{array}{c}-0.945 * * \\
(0.408)\end{array}$ & $\begin{array}{c}-0.052 * * \\
(0.023)\end{array}$ & $\begin{array}{l}-0.012 \\
(0.020)\end{array}$ & $\begin{array}{c}0.186 \\
(0.251)\end{array}$ & $\begin{array}{c}0.082 \\
(0.198)\end{array}$ \\
\hline$C_{i t-1} \cdot y_{t}$ & $\begin{array}{l}-0.017 \\
(0.086)\end{array}$ & $\begin{array}{c}0.034 \\
(0.082)\end{array}$ & $\begin{array}{l}-0.014 \\
(0.082)\end{array}$ & $\begin{array}{l}-0.030 \\
(0.082)\end{array}$ & $\begin{array}{c}0.818 * * \\
(0.415)\end{array}$ & $\begin{array}{c}0.644 \\
(0.464)\end{array}$ \\
\hline$C_{i t-1} \cdot y_{t-1}$ & $\begin{array}{l}-0.171 \\
(0.127)\end{array}$ & $\begin{array}{l}-0.141 \\
(0.114)\end{array}$ & $\begin{array}{l}-0.166 \\
(0.124)\end{array}$ & $\begin{array}{l}-0.154 \\
(0.124)\end{array}$ & $\begin{array}{c}-1.230 * * \\
(0.594)\end{array}$ & $\begin{array}{l}-0.916 \\
(0.607)\end{array}$ \\
\hline$C_{i t-1} \cdot y_{t-2}$ & $\begin{array}{c}0.173 \\
(0.166)\end{array}$ & $\begin{array}{c}0.102 \\
(0.156)\end{array}$ & $\begin{array}{c}0.168 \\
(0.160)\end{array}$ & $\begin{array}{c}0.153 \\
(0.163)\end{array}$ & $\begin{array}{c}0.138 \\
(0.488)\end{array}$ & $\begin{array}{l}-0.185 \\
(0.556)\end{array}$ \\
\hline$C_{i t-1} \cdot y_{t-3}$ & $\begin{array}{c}0.020 \\
(0.170)\end{array}$ & $\begin{array}{c}0.038 \\
(0.161)\end{array}$ & $\begin{array}{c}0.020 \\
(0.164)\end{array}$ & $\begin{array}{c}0.020 \\
(0.169)\end{array}$ & $\begin{array}{c}0.379 \\
(0.570)\end{array}$ & $\begin{array}{c}0.729 \\
(0.611)\end{array}$ \\
\hline$C_{i t-1} \cdot y_{t-4}$ & $\begin{array}{l}-0.059 \\
(0.088)\end{array}$ & $\begin{array}{l}-0.031 \\
(0.086)\end{array}$ & $\begin{array}{l}-0.055 \\
(0.085)\end{array}$ & $\begin{array}{l}-0.051 \\
(0.087)\end{array}$ & $\begin{array}{c}0.147 \\
(0.430)\end{array}$ & $\begin{array}{l}-0.032 \\
(0.432)\end{array}$ \\
\hline Continued & & & & & & \\
\hline
\end{tabular}


Table A3 cont'd: Estimated Coefficients

\begin{tabular}{|c|c|c|c|c|c|c|}
\hline Variables & OLS & (2) & $\begin{array}{c}(3) \\
\text { GMM SYS t-2: } \\
\text { GMM-Style } \\
\text { Instruments }\end{array}$ & $\begin{array}{c}(4) \\
\text { GMM SYS t-3: } \\
\text { GMM-Style } \\
\text { Instruments }\end{array}$ & $\begin{array}{c}(5) \\
\text { GMM SYS t-2: } \\
\text { Stacked } \\
\text { Instruments }\end{array}$ & $\begin{array}{c}(6) \\
\text { GMM SYS t-3: } \\
\text { Stacked } \\
\text { Instruments }\end{array}$ \\
\hline$S_{i t-1} \cdot \Delta i_{t}^{3 M}$ & $\begin{array}{c}-0.097 * \\
(0.051)\end{array}$ & $\begin{array}{l}-0.079 \\
(0.053)\end{array}$ & $\begin{array}{c}-0.096^{*} \\
(0.050)\end{array}$ & $\begin{array}{c}-0.091 * \\
(0.051)\end{array}$ & $\begin{array}{c}0.243 \\
(0.329)\end{array}$ & $\begin{array}{c}0.218 \\
(0.332)\end{array}$ \\
\hline$S_{i t-1} \cdot \Delta i_{t-1}^{3 M}$ & $\begin{array}{l}-0.015 \\
(0.083)\end{array}$ & $\begin{array}{l}-0.028 \\
(0.081)\end{array}$ & $\begin{array}{l}-0.016 \\
(0.081)\end{array}$ & $\begin{array}{l}-0.015 \\
(0.082)\end{array}$ & $\begin{array}{c}-0.973 * * \\
(0.474)\end{array}$ & $\begin{array}{l}-0.593 \\
(0.420)\end{array}$ \\
\hline$S_{i t-1} \cdot \Delta i_{t-2}^{3 M}$ & $\begin{array}{c}0.030 \\
(0.063)\end{array}$ & $\begin{array}{c}0.020 \\
(0.059)\end{array}$ & $\begin{array}{c}0.029 \\
(0.061)\end{array}$ & $\begin{array}{c}0.029 \\
(0.062)\end{array}$ & $\begin{array}{l}-0.238 \\
(0.274)\end{array}$ & $\begin{array}{l}-0.177 \\
(0.254)\end{array}$ \\
\hline$S_{i t-1} \cdot \Delta i_{t-3}^{3 M}$ & $\begin{array}{c}0.000 \\
(0.057)\end{array}$ & $\begin{array}{l}-0.003 \\
(0.055)\end{array}$ & $\begin{array}{c}0.003 \\
(0.056)\end{array}$ & $\begin{array}{l}-0.003 \\
(0.056)\end{array}$ & $\begin{array}{c}0.243 \\
(0.155)\end{array}$ & $\begin{array}{c}0.141 \\
(0.155)\end{array}$ \\
\hline$S_{i t-1} \cdot \Delta i_{t-4}^{3 M}$ & $\begin{array}{c}0.059 \\
(0.040)\end{array}$ & $\begin{array}{c}0.049 \\
(0.039)\end{array}$ & $\begin{array}{c}0.061 \\
(0.039)\end{array}$ & $\begin{array}{c}0.056 \\
(0.041)\end{array}$ & $\begin{array}{c}0.614 * * * \\
(0.226)\end{array}$ & $\begin{array}{c}0.313 \\
(0.225)\end{array}$ \\
\hline$\Delta h p_{t}$ & $\begin{array}{c}0.041 \\
(0.031)\end{array}$ & $\begin{array}{c}0.049 \\
(0.030)\end{array}$ & $\begin{array}{c}0.038 \\
(0.029)\end{array}$ & $\begin{array}{c}0.035 \\
(0.031)\end{array}$ & $\begin{array}{c}0.083 * * \\
(0.039)\end{array}$ & $\begin{array}{c}0.084 * * \\
(0.039)\end{array}$ \\
\hline$\Delta h p_{t-1}$ & $\begin{array}{c}0.112 * * * \\
(0.034)\end{array}$ & $\begin{array}{c}0.144 * * * \\
(0.035)\end{array}$ & $\begin{array}{c}0.107 * * * \\
(0.033)\end{array}$ & $\begin{array}{c}0.107 * * * \\
(0.034)\end{array}$ & $\begin{array}{c}0.175 * * * \\
(0.048)\end{array}$ & $\begin{array}{c}0.173 * * * \\
(0.046)\end{array}$ \\
\hline$\Delta h p_{t-2}$ & $\begin{array}{c}0.112 * * * \\
(0.037)\end{array}$ & $\begin{array}{c}0.147 * * * \\
(0.038)\end{array}$ & $\begin{array}{c}0.110 * * * \\
(0.035)\end{array}$ & $\begin{array}{c}0.107 * * * \\
(0.037)\end{array}$ & $\begin{array}{c}0.175 * * * \\
(0.044)\end{array}$ & $\begin{array}{c}0.169 * * * \\
(0.042)\end{array}$ \\
\hline$\Delta h p_{t-3}$ & $\begin{array}{c}0.086 * * \\
(0.040)\end{array}$ & $\begin{array}{c}0.115^{* * *} \\
(0.041)\end{array}$ & $\begin{array}{c}0.085 * * \\
(0.038)\end{array}$ & $\begin{array}{c}0.081 * * \\
(0.040)\end{array}$ & $\begin{array}{c}0.147 * * * \\
(0.047)\end{array}$ & $\begin{array}{c}0.144 * * * \\
(0.048)\end{array}$ \\
\hline$\Delta h p_{t-4}$ & $\begin{array}{c}0.040 \\
(0.036)\end{array}$ & $\begin{array}{c}0.075 * * \\
(0.034)\end{array}$ & $\begin{array}{c}0.038 \\
(0.035)\end{array}$ & $\begin{array}{c}0.036 \\
(0.036)\end{array}$ & $\begin{array}{c}0.076 \\
(0.054)\end{array}$ & $\begin{array}{c}0.079 \\
(0.055)\end{array}$ \\
\hline$y_{t}$ & $\begin{array}{l}0.083^{*} \\
(0.045)\end{array}$ & $\begin{array}{c}0.123 * * \\
(0.048)\end{array}$ & $\begin{array}{l}0.077 * \\
(0.045)\end{array}$ & $\begin{array}{l}0.078^{*} \\
(0.046)\end{array}$ & $\begin{array}{l}0.135^{*} \\
(0.077)\end{array}$ & $\begin{array}{l}0.135^{*} \\
(0.077)\end{array}$ \\
\hline$y_{t-1}$ & $\begin{array}{l}-0.018 \\
(0.063)\end{array}$ & $\begin{array}{l}-0.041 \\
(0.059)\end{array}$ & $\begin{array}{l}-0.011 \\
(0.062)\end{array}$ & $\begin{array}{l}-0.021 \\
(0.064)\end{array}$ & $\begin{array}{c}0.033 \\
(0.097)\end{array}$ & $\begin{array}{c}0.020 \\
(0.097)\end{array}$ \\
\hline$y_{t-2}$ & $\begin{array}{l}-0.043 \\
(0.055)\end{array}$ & $\begin{array}{l}-0.049 \\
(0.051)\end{array}$ & $\begin{array}{l}-0.042 \\
(0.053)\end{array}$ & $\begin{array}{l}-0.037 \\
(0.055)\end{array}$ & $\begin{array}{l}-0.042 \\
(0.068)\end{array}$ & $\begin{array}{l}-0.046 \\
(0.074)\end{array}$ \\
\hline$y_{t-3}$ & $\begin{array}{c}0.007 \\
(0.063)\end{array}$ & $\begin{array}{c}0.041 \\
(0.062)\end{array}$ & $\begin{array}{c}0.005 \\
(0.062)\end{array}$ & $\begin{array}{c}0.006 \\
(0.063)\end{array}$ & $\begin{array}{l}-0.041 \\
(0.085)\end{array}$ & $\begin{array}{l}-0.020 \\
(0.087)\end{array}$ \\
\hline$y_{t-4}$ & $\begin{array}{c}0.024 \\
(0.040)\end{array}$ & $\begin{array}{c}0.002 \\
(0.038)\end{array}$ & $\begin{array}{c}0.026 \\
(0.039)\end{array}$ & $\begin{array}{c}0.019 \\
(0.039)\end{array}$ & $\begin{array}{c}0.030 \\
(0.057)\end{array}$ & $\begin{array}{c}0.014 \\
(0.053)\end{array}$ \\
\hline$\pi_{t}$ & $\begin{array}{c}0.061 \\
(0.064)\end{array}$ & $\begin{array}{c}0.081 \\
(0.063)\end{array}$ & $\begin{array}{c}0.055 \\
(0.062)\end{array}$ & $\begin{array}{c}0.059 \\
(0.063)\end{array}$ & $\begin{array}{c}0.036 \\
(0.091)\end{array}$ & $\begin{array}{c}0.014 \\
(0.091)\end{array}$ \\
\hline$\pi_{t-1}$ & $\begin{array}{c}0.060 \\
(0.081)\end{array}$ & $\begin{array}{c}0.099 \\
(0.075)\end{array}$ & $\begin{array}{c}0.054 \\
(0.079)\end{array}$ & $\begin{array}{c}0.054 \\
(0.081)\end{array}$ & $\begin{array}{c}0.227 * * \\
(0.112)\end{array}$ & $\begin{array}{l}0.240^{*} \\
(0.131)\end{array}$ \\
\hline$\pi_{t-2}$ & $\begin{array}{l}-0.051 \\
(0.064)\end{array}$ & $\begin{array}{l}-0.104 \\
(0.065)\end{array}$ & $\begin{array}{l}-0.048 \\
(0.064)\end{array}$ & $\begin{array}{l}-0.048 \\
(0.065)\end{array}$ & $\begin{array}{l}-0.076 \\
(0.088)\end{array}$ & $\begin{array}{l}-0.064 \\
(0.102)\end{array}$ \\
\hline$\pi_{t-3}$ & $\begin{array}{l}-0.096 \\
(0.071)\end{array}$ & $\begin{array}{l}-0.090 \\
(0.069)\end{array}$ & $\begin{array}{l}-0.095 \\
(0.069)\end{array}$ & $\begin{array}{l}-0.089 \\
(0.072)\end{array}$ & $\begin{array}{l}-0.122 \\
(0.090)\end{array}$ & $\begin{array}{l}-0.125 \\
(0.096)\end{array}$ \\
\hline$\pi_{t-4}$ & $\begin{array}{l}-0.020 \\
(0.038)\end{array}$ & $\begin{array}{l}-0.045 \\
(0.043)\end{array}$ & $\begin{array}{l}-0.026 \\
(0.039)\end{array}$ & $\begin{array}{l}-0.019 \\
(0.039)\end{array}$ & $\begin{array}{l}-0.061 \\
(0.055)\end{array}$ & $\begin{array}{l}-0.054 \\
(0.051)\end{array}$ \\
\hline Continued & & & & & & \\
\hline
\end{tabular}


Table A3 cont'd: Estimated Coefficients

\begin{tabular}{|c|c|c|c|c|c|c|}
\hline Variables & OLS & $\begin{array}{c}(2) \\
\text { WG }\end{array}$ & $\begin{array}{c}(3) \\
\text { GMM SYS t-2: } \\
\text { GMM-Style } \\
\text { Instruments }\end{array}$ & $\begin{array}{c}(4) \\
\text { GMM SYS t-3: } \\
\text { GMM-Style } \\
\text { Instruments }\end{array}$ & $\begin{array}{c}(5) \\
\text { GMM SYS t-2: } \\
\text { Stacked } \\
\text { Instruments }\end{array}$ & $\begin{array}{c}(6) \\
\text { GMM SYS t-3: } \\
\text { Stacked } \\
\text { Instruments }\end{array}$ \\
\hline Q2 & $\begin{array}{c}0.074 \\
(0.068)\end{array}$ & $\begin{array}{c}0.077 \\
(0.061)\end{array}$ & $\begin{array}{c}0.074 \\
(0.066)\end{array}$ & $\begin{array}{c}0.074 \\
(0.069)\end{array}$ & $\begin{array}{c}0.003 \\
(0.065)\end{array}$ & $\begin{array}{c}0.011 \\
(0.071)\end{array}$ \\
\hline Q3 & $\begin{array}{l}-0.083 \\
(0.072)\end{array}$ & $\begin{array}{l}-0.096 \\
(0.070)\end{array}$ & $\begin{array}{l}-0.081 \\
(0.071)\end{array}$ & $\begin{array}{l}-0.085 \\
(0.072)\end{array}$ & $\begin{array}{l}-0.066 \\
(0.073)\end{array}$ & $\begin{array}{l}-0.070 \\
(0.085)\end{array}$ \\
\hline Q4 & $\begin{array}{c}0.162 * * \\
(0.079)\end{array}$ & $\begin{array}{l}0.132 * \\
(0.075)\end{array}$ & $\begin{array}{c}0.164 * * \\
(0.078)\end{array}$ & $\begin{array}{c}0.161 * * \\
(0.080)\end{array}$ & $\begin{array}{c}0.172 * * \\
(0.084)\end{array}$ & $\begin{array}{c}0.152 \\
(0.100)\end{array}$ \\
\hline Constant & $\begin{array}{c}0.320 * * * \\
(0.099)\end{array}$ & $\begin{array}{c}0.440 * * * \\
(0.093)\end{array}$ & $\begin{array}{c}0.369 * * * \\
(0.104)\end{array}$ & $\begin{array}{c}0.314 * * * \\
(0.100)\end{array}$ & $\begin{array}{l}0.303 * \\
(0.159)\end{array}$ & $\begin{array}{c}0.253 \\
(0.188)\end{array}$ \\
\hline \multicolumn{7}{|l|}{ Regression Statistics: } \\
\hline Observations & 2,793 & 2,793 & 2,793 & 2,793 & 2,793 & 2,793 \\
\hline$R^{2}$ & 0.291 & 0.184 & - & - & - & - \\
\hline Number of Groups & - & 88 & 88 & 88 & 88 & 88 \\
\hline AR(1) P-value & 0.00 & 0.03 & 0.00 & 0.00 & 0.00 & 0.00 \\
\hline AR(2) P-value & 0.01 & 0.75 & 0.46 & 0.31 & 0.03 & 0.18 \\
\hline Sargan P-value & - & - & 0.00 & 0.02 & 0.00 & 0.00 \\
\hline Hansen P-value & - & - & 1.00 & 1.00 & 1.00 & 1.00 \\
\hline Max \# of lags & - & - & $1-2$ & $2-3$ & $1-16$ & $2-16$ \\
\hline \# of instruments & - & - & 926 & 936 & 122 & 117 \\
\hline
\end{tabular}

Notes : Dependent variable is the first difference of log quarterly loan volume, i.e. approximately the quarter on quarter loan growth rate. Cluster robust standard errors, at bank level, in parentheses. OLS stands for Ordinary Least Squares, WG stands for Within Groups using the deviations from means transformation. GMM stands for Generalised Method of Moments. GMM is implemented using both levels and first differenced equations (System GMM) as well as different instrument structures (GMM-Style or Stacked). Column (3) uses GMM-style instruments and lags from $t-2$ to $t-3$. Column (4) uses GMM-style instruments and lags from $t-3$ to $t-4$. Column (5) uses stacked instruments and lags from $t-2$ up to $t-16$ as instruments. Column (6) uses stacked instruments and lags from $t-3$ up to $t-16$. All estimations in columns (2)-(6) use fixed effects that are adjusted to account for mergers in our data set. $* * *$ $p<0.01, * * p<0.05, * p<0.1$

\section{A.4 Immediate vs. long-run effects}

Figure 2 requires a set of calculations and values. The partial derivative of equation (3), according to the EVA, with respect to $\Delta i_{t}^{3 M}=\Delta i_{t}^{10 Y}=\Delta i_{t}$ yields ${ }^{17}$

$$
\frac{\partial \Delta \ln L_{i t}}{\partial \Delta i_{t}}=\beta_{1,0}\left(\frac{\rho}{E l i g C}\right)+\beta_{2,0} B+\beta_{3,0} C+\beta_{4,0}+\beta_{5,0},
$$

which determines the immediate effect of an interest rate shock $\Delta i_{t}=100 \mathrm{bp}$ at time $t$ in Figure 2. The individual bank characteristics are evaluated as sample means, which can be found in

17 The analysis for the EA is identical and simply requires that one exchange $\rho$ with $\gamma$. 
Table A4. The remaining punctual effects can be summarized by the following equations

$$
\begin{aligned}
\frac{\partial \Delta \ln L_{i t+1}}{\partial \Delta i_{t}} & =\left(\beta_{1,1}+\alpha \beta_{1,0}\right)\left(\frac{\rho}{E l i g C}\right)+\left(\beta_{2,1}+\alpha \beta_{2,0}\right) B+\left(\beta_{3,1}+\alpha \beta_{3,0}\right) C \\
& +\left[\left(\beta_{4,1}+\beta_{5,1}\right)+\alpha\left(\beta_{4,0}+\beta_{5,0}\right)\right] \\
\frac{\partial \Delta \ln L_{i t+2}}{\partial \Delta i_{t}} & =\left(\beta_{1,2}+\alpha \beta_{1,1}+\alpha^{2} \beta_{1,0}\right)\left(\frac{\rho}{E l i g C}\right) \\
& +\left(\beta_{2,2}+\alpha \beta_{2,1}+\alpha^{2} \beta_{2,0}\right) B \\
& +\left(\beta_{3,2}+\alpha \beta_{3,1}+\alpha^{2} \beta_{3,0}\right) C \\
& +\left[\left(\beta_{4,2}+\beta_{5,2}\right)+\alpha\left(\beta_{4,1}+\beta_{5,1}\right)+\alpha^{2}\left(\beta_{4,0}+\beta_{5,0}\right)\right] \\
\frac{\partial \Delta \ln L_{i t+3}}{\partial \Delta i_{t}} & =\left(\beta_{1,3}+\alpha \beta_{1,2}+\alpha^{2} \beta_{1,1}+\alpha^{3} \beta_{1,0}\right)\left(\frac{\rho}{E_{l i g} C}\right) \\
& +\left(\beta_{2,3}+\alpha \beta_{2,2}+\alpha^{2} \beta_{2,1}+\alpha^{3} \beta_{2,0}\right) B \\
& +\left(\beta_{3,3}+\alpha \beta_{3,2}+\alpha^{2} \beta_{3,1}+\alpha^{3} \beta_{3,0}\right) C \\
& +\left[\left(\beta_{4,3}+\beta_{5,3}\right)+\alpha\left(\beta_{4,2}+\beta_{5,2}\right)+\alpha^{2}\left(\beta_{4,1}+\beta_{5,1}\right)+\alpha^{3}\left(\beta_{4,0}+\beta_{5,0}\right)\right] \\
\frac{\partial \Delta \ln L_{i t+4}}{\partial \Delta i_{t}} & =\left(\beta_{1,4}+\alpha \beta_{1,3}+\alpha^{2} \beta_{1,2}+\alpha^{3} \beta_{1,1}+\alpha^{4} \beta_{1,0}\right)\left(\frac{\rho}{E l i g C}\right) \\
& +\left(\beta_{2,4}+\alpha \beta_{2,3}+\alpha^{2} \beta_{2,2}+\alpha^{3} \beta_{2,1}+\alpha^{4} \beta_{2,0}\right) B \\
& +\left(\beta_{3,4}+\alpha \beta_{3,3}+\alpha^{2} \beta_{3,2}+\alpha^{3} \beta_{3,1}+\alpha^{4} \beta_{3,0}\right) C \\
& +\left[\left(\beta_{4,4}+\beta_{5,4}\right)+\alpha\left(\beta_{4,3}+\beta_{5,3}\right)+\alpha^{2}\left(\beta_{4,2}+\beta_{5,2}\right)+\alpha^{3}\left(\beta_{4,1}+\beta_{5,1}\right)+\alpha^{4}\left(\beta_{4,0}+\beta_{5,0}\right)\right] .
\end{aligned}
$$

The calculation of the cumulative long-run effect at time $t+4$ in Figure 2 is significantly more algebraically involved. It requires the sum of equations (6), (7), (8), (9) and (10). Alternatively, take the long-run coefficients displayed in Table 3, multiply them by their corresponding average values reported in Table A4 and sum up.

Finally, Table A4 summarizes the exact values that are needed for the calculations set forth above and are used in Figure 2. To perform the ceteris paribus analysis, we hold all other factors constant and equal to their average value. Our main variable, interest rate risk exposure, takes on three values determined by the distribution of upward interest rate risk in 2013Q3. 
Table A4: Exact Values for Figure 2

\begin{tabular}{lccc}
\hline \hline Variable & $\begin{array}{c}\text { Exposure equal } \\
\text { to 1st decile }\end{array}$ & Average Bank & $\begin{array}{c}\text { Exposure equal } \\
\text { to 9th decile }\end{array}$ \\
\hline $\begin{array}{l}\text { Realized Interest Rate Risk }(\rho / E l i g C) \times 100 \\
\text { (fraction of eligible capital) }\end{array}$ & 0.32257 & -4.42237 & -8.81485 \\
Normalized Excess Capital $(C) \times 100$ & -10.34936 & -10.34936 & -10.34936 \\
Normalized Excess Liquidity $(B) \times 100$ & 10.791 & 10.791 & 10.791 \\
\hline Short-term interest rate $\left(\Delta i^{3 M}=\Delta i=1\right) \times 100$ & $100 \mathrm{bp}$ & $100 \mathrm{bp}$ & $100 \mathrm{bp}$ \\
Long-term interest rate $\left(\Delta i^{10 Y}=\Delta i=1\right) \times 100$ & $100 \mathrm{bp}$ & $100 \mathrm{bp}$ & $100 \mathrm{bp}$ \\
\hline \hline
\end{tabular}

Notes : All values correspond to 2013Q3. We recover the average values of normalized excess capital and liquidity in lines 2 and 3 respectively. Importantly, we recover three values $\left(10^{\text {th }}\right.$ percentile, average value, $90^{\text {th }}$ percentile) of the upward interest rate risk exposure distribution in 2013Q3 in the first line. The values have already been multiplied by 100 , i.e. the 100 basis point increase in interest rates. 


\section{A.5 Panel bias robustness}

Table A5: Panel Bias Regression Comparisons

\begin{tabular}{|c|c|c|c|c|}
\hline Variables & $\begin{array}{c}(1) \\
T \geq 10\end{array}$ & $\begin{array}{c}(2) \\
T \geq 15\end{array}$ & $\begin{array}{c}\text { (3) } \\
T \geq 20\end{array}$ & $\begin{array}{c}(4) \\
\text { All Panels }\end{array}$ \\
\hline$\Delta \ln L_{i t-1}$ & $\begin{array}{c}0.320 * * * \\
(0.042)\end{array}$ & $\begin{array}{c}0.320 * * * \\
(0.043)\end{array}$ & $\begin{array}{c}0.320 * * * \\
(0.043)\end{array}$ & $\begin{array}{c}0.320 * * * \\
(0.042)\end{array}$ \\
\hline$\left(\frac{\rho_{i t-1} \times \Delta i_{t}}{E \operatorname{EligC} C_{i t-1}}\right)_{i t}$ & $\begin{array}{c}1.924 \\
(2.117)\end{array}$ & $\begin{array}{c}1.951 \\
(2.117)\end{array}$ & $\begin{array}{c}2.156 \\
(2.132)\end{array}$ & $\begin{array}{c}1.936 \\
(2.107)\end{array}$ \\
\hline$\left(\frac{\rho_{i t-1} \times \Delta i_{t}}{E l i g C_{i t-1}}\right)_{i t-1}$ & $\begin{array}{c}1.275 \\
(2.708)\end{array}$ & $\begin{array}{c}1.128 \\
(2.710)\end{array}$ & $\begin{array}{c}1.048 \\
(2.720)\end{array}$ & $\begin{array}{c}1.235 \\
(2.694)\end{array}$ \\
\hline$\left(\frac{\rho_{i t-1} \times \Delta i_{t}}{E l i g C_{i t-1}}\right)_{i t-2}$ & $\begin{array}{l}-2.714 \\
(2.116)\end{array}$ & $\begin{array}{l}-2.595 \\
(2.112)\end{array}$ & $\begin{array}{l}-2.537 \\
(2.125)\end{array}$ & $\begin{array}{l}-2.472 \\
(2.112)\end{array}$ \\
\hline$\left(\frac{\rho_{i t-1} \times \Delta i_{t}}{E l i g C_{i t-1}}\right)_{i t-3}$ & $\begin{array}{c}6.612 * * * \\
(1.694)\end{array}$ & $\begin{array}{c}6.496 * * * \\
(1.695)\end{array}$ & $\begin{array}{c}6.652 * * * \\
(1.698)\end{array}$ & $\begin{array}{c}6.407 * * * \\
(1.656)\end{array}$ \\
\hline$\left(\frac{\rho_{i t-1} \times \Delta i_{t}}{E l i g C_{i t-1}}\right)_{i t-4}$ & $\begin{array}{l}-1.053 \\
(1.657)\end{array}$ & $\begin{array}{l}-1.132 \\
(1.659)\end{array}$ & $\begin{array}{l}-1.221 \\
(1.685)\end{array}$ & $\begin{array}{l}-1.016 \\
(1.613)\end{array}$ \\
\hline$B_{i t-1} \cdot \Delta i_{t}^{3 M}$ & $\begin{array}{l}-0.071 \\
(0.108)\end{array}$ & $\begin{array}{l}-0.069 \\
(0.108)\end{array}$ & $\begin{array}{l}-0.055 \\
(0.109)\end{array}$ & $\begin{array}{l}-0.073 \\
(0.108)\end{array}$ \\
\hline$B_{i t-1} \cdot \Delta i_{t-1}^{3 M}$ & $\begin{array}{c}0.095 \\
(0.176)\end{array}$ & $\begin{array}{c}0.092 \\
(0.177)\end{array}$ & $\begin{array}{c}0.077 \\
(0.178)\end{array}$ & $\begin{array}{c}0.097 \\
(0.174)\end{array}$ \\
\hline$B_{i t-1} \cdot \Delta i_{t-2}^{3 M}$ & $\begin{array}{c}0.066 \\
(0.183)\end{array}$ & $\begin{array}{c}0.071 \\
(0.184)\end{array}$ & $\begin{array}{c}0.086 \\
(0.187)\end{array}$ & $\begin{array}{c}0.065 \\
(0.181)\end{array}$ \\
\hline$B_{i t-1} \cdot \Delta i_{t-3}^{3 M}$ & $\begin{array}{l}-0.030 \\
(0.126)\end{array}$ & $\begin{array}{l}-0.034 \\
(0.126)\end{array}$ & $\begin{array}{l}-0.046 \\
(0.127)\end{array}$ & $\begin{array}{l}-0.033 \\
(0.122)\end{array}$ \\
\hline$B_{i t-1} \cdot \Delta i_{t-4}^{3 M}$ & $\begin{array}{l}-0.097 \\
(0.082)\end{array}$ & $\begin{array}{l}-0.095 \\
(0.082)\end{array}$ & $\begin{array}{l}-0.097 \\
(0.083)\end{array}$ & $\begin{array}{l}-0.096 \\
(0.079)\end{array}$ \\
\hline$C_{i t-1} \cdot \Delta i_{t}^{3 M}$ & $\begin{array}{l}-0.179 \\
(0.277)\end{array}$ & $\begin{array}{l}-0.139 \\
(0.280)\end{array}$ & $\begin{array}{l}-0.149 \\
(0.285)\end{array}$ & $\begin{array}{l}-0.160 \\
(0.276)\end{array}$ \\
\hline$C_{i t-1} \cdot \Delta i_{t-1}^{3 M}$ & $\begin{array}{c}0.287 \\
(0.354)\end{array}$ & $\begin{array}{c}0.304 \\
(0.359)\end{array}$ & $\begin{array}{c}0.306 \\
(0.369)\end{array}$ & $\begin{array}{c}0.303 \\
(0.354)\end{array}$ \\
\hline$C_{i t-1} \cdot \Delta i_{t-2}^{3 M}$ & $\begin{array}{c}0.159 \\
(0.376)\end{array}$ & $\begin{array}{c}0.161 \\
(0.380)\end{array}$ & $\begin{array}{c}0.141 \\
(0.386)\end{array}$ & $\begin{array}{c}0.150 \\
(0.377)\end{array}$ \\
\hline$C_{i t-1} \cdot \Delta i_{t-3}^{3 M}$ & $\begin{array}{c}0.150 \\
(0.208)\end{array}$ & $\begin{array}{c}0.156 \\
(0.209)\end{array}$ & $\begin{array}{c}0.179 \\
(0.212)\end{array}$ & $\begin{array}{c}0.181 \\
(0.210)\end{array}$ \\
\hline$C_{i t-1} \cdot \Delta i_{t-4}^{3 M}$ & $\begin{array}{l}-0.488 \\
(0.304)\end{array}$ & $\begin{array}{l}-0.486 \\
(0.305)\end{array}$ & $\begin{array}{l}-0.487 \\
(0.319)\end{array}$ & $\begin{array}{l}-0.491 \\
(0.297)\end{array}$ \\
\hline Continued & & & & \\
\hline
\end{tabular}


Table A5 cont'd: Panel Bias Regression Comparisons

\begin{tabular}{|c|c|c|c|c|}
\hline Variables & $\begin{array}{c}(1) \\
T \geq 10\end{array}$ & $\begin{array}{c}(2) \\
T \geq 15\end{array}$ & $\begin{array}{c}\text { (3) } \\
T \geq 20\end{array}$ & $\begin{array}{c}\text { (4) } \\
\text { All Panels }\end{array}$ \\
\hline$\Delta i_{t}^{3 M}$ & $\begin{array}{c}-0.461 * * * \\
(0.164)\end{array}$ & $\begin{array}{c}-0.471 * * * \\
(0.165)\end{array}$ & $\begin{array}{c}-0.460 * * * \\
(0.167)\end{array}$ & $\begin{array}{c}-0.461 * * * \\
(0.164)\end{array}$ \\
\hline$\Delta i_{t-1}^{3 M}$ & $\begin{array}{c}-0.319 * * \\
(0.145)\end{array}$ & $\begin{array}{c}-0.315 * * \\
(0.145)\end{array}$ & $\begin{array}{c}-0.318^{* *} \\
(0.146)\end{array}$ & $\begin{array}{c}-0.332 * * \\
(0.145)\end{array}$ \\
\hline$\Delta i_{t-2}^{3 M}$ & $\begin{array}{c}-0.715^{* * *} \\
(0.181)\end{array}$ & $\begin{array}{c}-0.714 * * * \\
(0.182)\end{array}$ & $\begin{array}{c}-0.709 * * * \\
(0.185)\end{array}$ & $\begin{array}{c}-0.703 * * * \\
(0.181)\end{array}$ \\
\hline$\Delta i_{t-3}^{3 M}$ & $\begin{array}{l}-0.187 \\
(0.129)\end{array}$ & $\begin{array}{l}-0.187 \\
(0.132)\end{array}$ & $\begin{array}{l}-0.201 \\
(0.133)\end{array}$ & $\begin{array}{l}-0.201 \\
(0.128)\end{array}$ \\
\hline$\Delta i_{t-4}^{3 M}$ & $\begin{array}{l}-0.028 \\
(0.142)\end{array}$ & $\begin{array}{l}-0.024 \\
(0.143)\end{array}$ & $\begin{array}{l}-0.027 \\
(0.146)\end{array}$ & $\begin{array}{l}-0.032 \\
(0.140)\end{array}$ \\
\hline$\Delta i_{t}^{10 Y}$ & $\begin{array}{c}0.084 \\
(0.107)\end{array}$ & $\begin{array}{c}0.104 \\
(0.107)\end{array}$ & $\begin{array}{c}0.111 \\
(0.109)\end{array}$ & $\begin{array}{c}0.076 \\
(0.106)\end{array}$ \\
\hline$\Delta i_{t-1}^{10 Y}$ & $\begin{array}{c}-0.160 * \\
(0.091)\end{array}$ & $\begin{array}{l}-0.164 * \\
(0.092)\end{array}$ & $\begin{array}{c}-0.157 * \\
(0.093)\end{array}$ & $\begin{array}{l}-0.155^{*} \\
(0.091)\end{array}$ \\
\hline$\Delta i_{t-2}^{10 Y}$ & $\begin{array}{l}-0.058 \\
(0.118)\end{array}$ & $\begin{array}{l}-0.057 \\
(0.119)\end{array}$ & $\begin{array}{l}-0.066 \\
(0.122)\end{array}$ & $\begin{array}{l}-0.061 \\
(0.117)\end{array}$ \\
\hline$\Delta i_{t-3}^{10 Y}$ & $\begin{array}{c}0.040 \\
(0.120)\end{array}$ & $\begin{array}{c}0.050 \\
(0.122)\end{array}$ & $\begin{array}{c}0.061 \\
(0.125)\end{array}$ & $\begin{array}{c}0.046 \\
(0.120)\end{array}$ \\
\hline$\Delta i_{t-4}^{10 Y}$ & $\begin{array}{l}-0.026 \\
(0.114)\end{array}$ & $\begin{array}{l}-0.027 \\
(0.115)\end{array}$ & $\begin{array}{l}-0.026 \\
(0.117)\end{array}$ & $\begin{array}{l}-0.029 \\
(0.113)\end{array}$ \\
\hline$C_{i t-1}$ & $\begin{array}{c}0.006 \\
(0.245)\end{array}$ & $\begin{array}{c}0.048 \\
(0.248)\end{array}$ & $\begin{array}{c}0.040 \\
(0.252)\end{array}$ & $\begin{array}{c}0.016 \\
(0.244)\end{array}$ \\
\hline$B_{i t-1}$ & $\begin{array}{c}0.027 \\
(0.044)\end{array}$ & $\begin{array}{c}0.031 \\
(0.044)\end{array}$ & $\begin{array}{c}0.030 \\
(0.045)\end{array}$ & $\begin{array}{c}0.029 \\
(0.044)\end{array}$ \\
\hline$S_{i t-1}$ & $\begin{array}{c}-0.936 * * \\
(0.408)\end{array}$ & $\begin{array}{c}-0.919 * * \\
(0.409)\end{array}$ & $\begin{array}{c}-0.937 * * \\
(0.412)\end{array}$ & $\begin{array}{c}-0.945 * * \\
(0.408)\end{array}$ \\
\hline$C_{i t-1} \cdot y_{t}$ & $\begin{array}{c}0.041 \\
(0.082)\end{array}$ & $\begin{array}{c}0.030 \\
(0.083)\end{array}$ & $\begin{array}{c}0.046 \\
(0.085)\end{array}$ & $\begin{array}{c}0.034 \\
(0.082)\end{array}$ \\
\hline$C_{i t-1} \cdot y_{t-1}$ & $\begin{array}{l}-0.139 \\
(0.114)\end{array}$ & $\begin{array}{l}-0.148 \\
(0.114)\end{array}$ & $\begin{array}{l}-0.174 \\
(0.118)\end{array}$ & $\begin{array}{l}-0.141 \\
(0.114)\end{array}$ \\
\hline$C_{i t-1} \cdot y_{t-2}$ & $\begin{array}{c}0.087 \\
(0.156)\end{array}$ & $\begin{array}{c}0.117 \\
(0.160)\end{array}$ & $\begin{array}{c}0.139 \\
(0.164)\end{array}$ & $\begin{array}{c}0.102 \\
(0.156)\end{array}$ \\
\hline$C_{i t-1} \cdot y_{t-3}$ & $\begin{array}{c}0.056 \\
(0.162)\end{array}$ & $\begin{array}{c}0.040 \\
(0.167)\end{array}$ & $\begin{array}{c}0.023 \\
(0.171)\end{array}$ & $\begin{array}{c}0.038 \\
(0.161)\end{array}$ \\
\hline$C_{i t-1} \cdot y_{t-4}$ & $\begin{array}{l}-0.037 \\
(0.086)\end{array}$ & $\begin{array}{l}-0.042 \\
(0.089)\end{array}$ & $\begin{array}{l}-0.033 \\
(0.090)\end{array}$ & $\begin{array}{l}-0.031 \\
(0.086)\end{array}$ \\
\hline Continuec & & & & \\
\hline
\end{tabular}


Table A5 cont'd: Panel Bias Regression Comparisons

\begin{tabular}{|c|c|c|c|c|}
\hline Variables & $\begin{array}{c}(1) \\
T \geq 10\end{array}$ & $\begin{array}{c}(2) \\
T \geq 15\end{array}$ & $\begin{array}{c}(3) \\
T \geq 20\end{array}$ & $\begin{array}{c}\text { (4) } \\
\text { All Panels }\end{array}$ \\
\hline$S_{i t-1} \cdot \Delta i_{t}^{3 M}$ & $\begin{array}{l}-0.077 \\
(0.053)\end{array}$ & $\begin{array}{l}-0.076 \\
(0.053)\end{array}$ & $\begin{array}{l}-0.083 \\
(0.053)\end{array}$ & $\begin{array}{l}-0.079 \\
(0.053)\end{array}$ \\
\hline$S_{i t-1} \cdot \Delta i_{t-1}^{3 M}$ & $\begin{array}{l}-0.033 \\
(0.081)\end{array}$ & $\begin{array}{l}-0.036 \\
(0.082)\end{array}$ & $\begin{array}{l}-0.030 \\
(0.082)\end{array}$ & $\begin{array}{l}-0.028 \\
(0.081)\end{array}$ \\
\hline$S_{i t-1} \cdot \Delta i_{t-2}^{3 M}$ & $\begin{array}{c}0.025 \\
(0.059)\end{array}$ & $\begin{array}{c}0.029 \\
(0.060)\end{array}$ & $\begin{array}{c}0.022 \\
(0.060)\end{array}$ & $\begin{array}{c}0.020 \\
(0.059)\end{array}$ \\
\hline$S_{i t-1} \cdot \Delta i_{t-3}^{3 M}$ & $\begin{array}{l}-0.004 \\
(0.056)\end{array}$ & $\begin{array}{l}-0.007 \\
(0.056)\end{array}$ & $\begin{array}{l}-0.000 \\
(0.056)\end{array}$ & $\begin{array}{l}-0.003 \\
(0.055)\end{array}$ \\
\hline$S_{i t-1} \cdot \Delta i_{t-4}^{3 M}$ & $\begin{array}{c}0.048 \\
(0.039)\end{array}$ & $\begin{array}{c}0.048 \\
(0.040)\end{array}$ & $\begin{array}{c}0.047 \\
(0.040)\end{array}$ & $\begin{array}{c}0.049 \\
(0.039)\end{array}$ \\
\hline$\Delta h p_{t}$ & $\begin{array}{c}0.048 \\
(0.030)\end{array}$ & $\begin{array}{c}0.048 \\
(0.030)\end{array}$ & $\begin{array}{l}0.053 * \\
(0.031)\end{array}$ & $\begin{array}{c}0.049 \\
(0.030)\end{array}$ \\
\hline$\Delta h p_{t-1}$ & $\begin{array}{c}0.143 * * * \\
(0.035)\end{array}$ & $\begin{array}{c}0.144 * * * \\
(0.035)\end{array}$ & $\begin{array}{c}0.145 * * * \\
(0.036)\end{array}$ & $\begin{array}{c}0.144 * * * \\
(0.035)\end{array}$ \\
\hline$\Delta h p_{t-2}$ & $\begin{array}{c}0.145 * * * \\
(0.038)\end{array}$ & $\begin{array}{c}0.147 * * * \\
(0.038)\end{array}$ & $\begin{array}{c}0.151 * * * \\
(0.039)\end{array}$ & $\begin{array}{c}0.147 * * * \\
(0.038)\end{array}$ \\
\hline$\Delta h p_{t-3}$ & $\begin{array}{c}0.114 * * * \\
(0.042)\end{array}$ & $\begin{array}{c}0.114 * * * \\
(0.042)\end{array}$ & $\begin{array}{c}0.119 * * * \\
(0.043)\end{array}$ & $\begin{array}{c}0.115 * * * \\
(0.041)\end{array}$ \\
\hline$\Delta h p_{t-4}$ & $\begin{array}{c}0.073 * * \\
(0.034)\end{array}$ & $\begin{array}{l}0.068 * \\
(0.035)\end{array}$ & $\begin{array}{c}0.072 * * \\
(0.035)\end{array}$ & $\begin{array}{c}0.075^{* *} \\
(0.034)\end{array}$ \\
\hline$y_{t}$ & $\begin{array}{c}0.121 * * \\
(0.049)\end{array}$ & $\begin{array}{c}0.118 * * \\
(0.049)\end{array}$ & $\begin{array}{c}0.114 * * \\
(0.050)\end{array}$ & $\begin{array}{c}0.123 * * \\
(0.048)\end{array}$ \\
\hline$y_{t-1}$ & $\begin{array}{l}-0.041 \\
(0.059)\end{array}$ & $\begin{array}{l}-0.034 \\
(0.058)\end{array}$ & $\begin{array}{l}-0.034 \\
(0.059)\end{array}$ & $\begin{array}{l}-0.041 \\
(0.059)\end{array}$ \\
\hline$y_{t-2}$ & $\begin{array}{l}-0.047 \\
(0.051)\end{array}$ & $\begin{array}{l}-0.062 \\
(0.050)\end{array}$ & $\begin{array}{l}-0.059 \\
(0.051)\end{array}$ & $\begin{array}{l}-0.049 \\
(0.051)\end{array}$ \\
\hline$y_{t-3}$ & $\begin{array}{c}0.039 \\
(0.062)\end{array}$ & $\begin{array}{c}0.049 \\
(0.063)\end{array}$ & $\begin{array}{c}0.048 \\
(0.063)\end{array}$ & $\begin{array}{c}0.041 \\
(0.062)\end{array}$ \\
\hline$y_{t-4}$ & $\begin{array}{c}0.002 \\
(0.038)\end{array}$ & $\begin{array}{c}0.001 \\
(0.039)\end{array}$ & $\begin{array}{l}-0.002 \\
(0.039)\end{array}$ & $\begin{array}{c}0.002 \\
(0.038)\end{array}$ \\
\hline$\pi_{t}$ & $\begin{array}{c}0.079 \\
(0.064)\end{array}$ & $\begin{array}{c}0.079 \\
(0.064)\end{array}$ & $\begin{array}{c}0.080 \\
(0.066)\end{array}$ & $\begin{array}{c}0.081 \\
(0.063)\end{array}$ \\
\hline$\pi_{t-1}$ & $\begin{array}{c}0.103 \\
(0.076)\end{array}$ & $\begin{array}{c}0.106 \\
(0.077)\end{array}$ & $\begin{array}{c}0.117 \\
(0.078)\end{array}$ & $\begin{array}{c}0.099 \\
(0.075)\end{array}$ \\
\hline$\pi_{t-2}$ & $\begin{array}{l}-0.107 \\
(0.065)\end{array}$ & $\begin{array}{l}-0.108 \\
(0.066)\end{array}$ & $\begin{array}{l}-0.116^{*} \\
(0.067)\end{array}$ & $\begin{array}{l}-0.104 \\
(0.065)\end{array}$ \\
\hline$\pi_{t-3}$ & $\begin{array}{l}-0.090 \\
(0.069)\end{array}$ & $\begin{array}{l}-0.097 \\
(0.070)\end{array}$ & $\begin{array}{l}-0.089 \\
(0.071)\end{array}$ & $\begin{array}{l}-0.090 \\
(0.069)\end{array}$ \\
\hline$\pi_{t-4}$ & $\begin{array}{l}-0.042 \\
(0.043)\end{array}$ & $\begin{array}{l}-0.038 \\
(0.043)\end{array}$ & $\begin{array}{l}-0.044 \\
(0.044)\end{array}$ & $\begin{array}{l}-0.045 \\
(0.043)\end{array}$ \\
\hline ontinued & & & & \\
\hline
\end{tabular}


Table A5 cont'd: Panel Bias Regression Comparisons

\begin{tabular}{lcccc}
\hline \hline \multirow{2}{*}{ Variables } & $(1)$ & $(2)$ & $(3)$ & $(4)$ \\
Q2 & $T \geq 10$ & $T \geq 15$ & $T \geq 20$ & All Panels \\
Q3 & 0.091 & 0.097 & 0.097 & 0.096 \\
& $(0.070)$ & $(0.071)$ & $(0.072)$ & $(0.070)$ \\
Q4 & -0.098 & -0.092 & -0.086 & -0.095 \\
& $(0.074)$ & $(0.075)$ & $(0.077)$ & $(0.074)$ \\
Constant & $0.131^{*}$ & $0.140^{*}$ & $0.143^{*}$ & $0.136^{*}$ \\
& $(0.075)$ & $(0.076)$ & $(0.078)$ & $(0.075)$ \\
\hline Regression Statistics: & -0.127 & -0.144 & -0.156 & -0.143 \\
Observations & $(0.137)$ & $(0.141)$ & $(0.143)$ & $(0.137)$ \\
$R^{2}$ & 2,770 & 2,731 & 2,672 & 2,793 \\
\# of Groups & 0.184 & 0.185 & 0.185 & 0.184 \\
\hline \hline
\end{tabular}

Notes : Dependent variable is the first difference of log quarterly loan volume, i.e. approximately the quarter on quarter loan growth rate. Estimates using the Within Groups deviations from means transformation. Cluster robust standard errors, at bank level, in parentheses. $* * * p<0.01$, ** $p<0.05, * p<0.1$ 


\section{Recent SNB Working Papers}

2017-4 Toni Beutler, Robert Bichsel, Adrian Bruhin and Jayson Danton: The Impact of Interest Rate Risk on Bank Lending.

2017-3 Raphael A. Auer, Andrei A. Levchenko and Philip Sauré: International Inflation Spillovers Through Input Linkages.

2017-2 Alain Galli, Christian Hepenstrick and Rolf Scheufele: Mixed-frequency models for tracking short-term economic developments in Switzerland.

2017-1 Matthias Gubler and Christoph Sax:

The Balassa-Samuelson Effect Reversed: New Evidence from OECD Countries.

2016-19 Jens H.E. Christensen and Signe Krogstrup: A Portfolio Model of Quantitative Easing.

2016-18 Jonas Meuli, Thomas Nellen and Thomas Nitschka: Securitisation, loan growth and bank funding: the Swiss experience since 1932.

2016-17 Rita Fleer, Barbara Rudolf and Mathias Zurlinden: Price change dispersion and time-varying pass-through to consumer prices.

2016-16 Gregor Bäurle, Daniel Kaufmann, Sylvia Kaufmann and Rodney W. Strachan: Changing dynamics at the zero lower bound.

2016-15 Adrian Jäggi, Martin Schlegel and Attilio Zanetti: Macroeconomic surprises, market environment and safe-haven currencies.

2016-14 Alain Galli: Sticky consumption and wealth effects in Switzerland.
2016-13 Gregor Bäurle and Rolf Scheufele: Credit cycles and real activity - the Swiss case.

2016-12 Silvio Schumacher: Networks and lending conditions: Empirical evidence from the Swiss franc money markets.

2016-11 Lucas Marc Fuhrer, Benjamin Müller and Luzian Steiner: The Liquidity Coverage Ratio and Security Prices

2016-10 Nikola Mirkov, Igor Pozdeev and Paul Söderlind: Toward Removal of the Swiss Franc Cap: Market Expectations and Verbal Interventions.

2016-9 Severin Bernhard and Till Ebner: Cross-border Spill over Effects of Unconventional Monetary Policieson Swiss Asset Prices.

2016-8 Pinar Yeşin: Capital Flows and the Swiss Franc.

2016-7 Signe Krogstrup and Cédric Tille: On the roles of different foreign currencies in European bank lending.

2016-6 Pascal Towbin and Sebastian Weber: Price expectations and the US housing boom.

2016-5 Raphael A. Auer and Cédric Tille: The banking sector and the Swiss financial account during the financial and European debt crises.

2016-4 Christian Hepenstrick and Massimiliano Marcellino: Forecasting with Large Unbalanced Datasets: The Mixed-Frequency Three-Pass Regression Filter. 
